\title{
Ag-Modified $\mathrm{LiMn}_{2} \mathrm{O}_{4}$ Cathode for Lithium-Ion Batteries: Coating Functionalization
}

\author{
Somia M. Abbas ${ }^{1}$, Ahmed M. Hashem ${ }^{1,2}$, Ashraf E. Abdel-Ghany ${ }^{1} \mathbb{1}$, Eman H. Ismail ${ }^{3}$, \\ Mário Kotlár ${ }^{4}$, Martin Winter ${ }^{2,5}$, Jie Li ${ }^{2}$ and Christian M. Julien ${ }^{6, * \mathbb{D}}$ \\ 1 Inorganic Chemistry Department, National Research Centre, 33 El Bohouth St. (former El Tahrir St.), \\ Dokki-Giza 12622, Egypt; somiamohamed223@gmail.com (S.M.A.); ahmedh242@yahoo.com (A.M.H.); \\ achraf_28@yahoo.com (A.E.A.-G.) \\ 2 Helmholtz-Institute Muenster (IEK-12) Forschungszentrum Juelich GmbH, Corrensstr. 46, \\ D-48149 Muenster, Germany; martin.winter@uni-muenster.de (M.W.); jie.li@uni-muenster.de (J.L.) \\ 3 Chemistry Department, Faculty of Science, Ain Shams University, Abbassia, Cairo 11566, Egypt; \\ eman_hamed@sci.asu.edu.eg \\ 4 Centre for Nanodiagnostics, Slovak University of Technology, University Science Park Bratislava Centre, \\ Vazovova 5, 81243 Bratislava, Slovakia; mario.kotlar@stuba.sk \\ 5 MEET Battery Research Center, Institute of Physical Chemistry, University of Muenster, Corrensstr. 46, \\ D-48149 Muenster, Germany \\ 6 Institut de Minéralogie, Physique des Matériaux et Cosmologie (IMPMC), Sorbonne Université, \\ CNRS-UMR 7590, 4 Place Jussieu, 75252 Paris, France \\ * Correspondence: christian.julien@sorbonne-universite.fr
}

Received: 12 August 2020; Accepted: 27 September 2020; Published: 5 October 2020

\begin{abstract}
In this work, the properties of silver-modified $\mathrm{LiMn}_{2} \mathrm{O}_{4}$ cathode materials are revisited. We study the influence of calcination atmosphere on the properties of the Ag-coated $\mathrm{LiMn}_{2} \mathrm{O}_{4}$ $(\mathrm{Ag} / \mathrm{LMO})$ and highlight the silver oxidation. The effect of the heat treatment in vacuum is compared with that in air by the characterization of the structure, specific surface area, Li transport properties and electrochemical performance of Ag/LMO composites. Surface analyses (XPS and Raman spectroscopy) show that the nature of the coating $(\sim 3 \mathrm{wt} . \%)$ differs with the calcination atmosphere: $\mathrm{Ag} / \mathrm{LMO}(\mathrm{v})$ calcined in vacuum displays $\mathrm{Ag}$ nanospheres and minor $\mathrm{AgO}$ content on its surface (specific surface area of $4.1 \mathrm{~m}^{2} \mathrm{~g}^{-1}$ ), while $\mathrm{Ag} / \mathrm{LMO}(\mathrm{a})$ treated in air is mainly covered by the AgO insulating phase (specific surface area of $0.6 \mathrm{~m}^{2} \mathrm{~g}^{-1}$ ). Electrochemical experiments emphasize that $\sim 3 \mathrm{wt} . \% \mathrm{Ag}$ coating is effective to minimize the drawbacks of the spinel $\mathrm{LiMn}_{2} \mathrm{O}_{4}$ (Mn dissolution, cycling instability, etc.). $\mathrm{The} \mathrm{Ag} / \mathrm{LMO}(\mathrm{v})$ electrode shows high capacity retention, good cyclability at $\mathrm{C} / 2$ rate and capacity fade of $0.06 \%$ per cycle (in 60 cycles).
\end{abstract}

Keywords: spinel $\mathrm{LiMn}_{2} \mathrm{O}_{4}$; $\mathrm{Ag}$ nanoparticles; surface modification; insertion electrode; cathode; Li-ion batteries

\section{Introduction}

Today, lithium-ion batteries (LIBs) appear to be the dominant electrochemical generators to power many systems such as electronics devices, tools, hybrid and full electric vehicles (EVs), etc. as they are able to rapidly store and release large quantities of electricity. Thus, one of the crucial parameters is the charge-discharge speed expressed in $n C$-rate $(n C$ is the rate of charge or discharge in $1 / n$ hour). Huge research efforts impel improving LIB technology, especially the performance of positive electrodes (cathodes), which are the limiting electrochemical components in terms of energy density and rate capability [1-3]. Due to its low toxicity, easy fabrication, high acceptability of environmental impact and good thermal stability, $\mathrm{LiMn}_{2} \mathrm{O}_{4}$ (LMO) is recognized to be one of the best candidates 
as cathode materials. However, it has poor cycle stability (presence of $\mathrm{Mn}^{3+} \mathrm{Jahn}-\mathrm{Teller}$ (JT) ions) and insufficient rate capability due its low electrical conductivity that should be improved for use in EVs' batteries [4-6].

Among the various techniques to prepare LMO materials, the solid-state reaction and coprecipitation methods are the most popular synthesis routes. The co-precipitation method is a wellknown wet-chemical technique for the growth of regular LMO particles with a narrow size distribution, compositional homogeneity and impurity free [7-11], while some impurities (i.e., $\mathrm{Mn}_{3} \mathrm{O}_{4}$ and $\mathrm{Mn}_{2} \mathrm{O}_{3}$ ) are often found in the powders prepared by solid state reaction [12]. Many strategies have been employed to improve the rate capability and cycle stability of $\mathrm{LiMn}_{2} \mathrm{O}_{4}$ : (i) synthesis of different morphologies of $\mathrm{LiMn}_{2} \mathrm{O}_{4}$ nanoparticles as a way to strike a balance between the good rate capability and high tap density to achieve excellent electrochemical performance [13-16]; (ii) suppression of the JT distortion by Li enrichment [17] or substituting the $\mathrm{Mn}$ ions with low-valent metal cations (divalent or trivalent) such as $\mathrm{Mg}^{2+}, \mathrm{Ni}^{2+}, \mathrm{Zn}^{2+}, \mathrm{Cr}^{3+}, \mathrm{Co}^{3+}$ and $\mathrm{Al}^{3+}$ [18-25], which decrease the content of $\mathrm{Mn}^{3+}$ (however, due to high amount of ion substitution and increased average valence state of $\mathrm{Mn}$, practical discharge capacity is limited to approximately $100 \mathrm{mAh} \mathrm{g}^{-1}$, which is only around $70 \%$ of the theoretical capacity (148 $\left.\mathrm{mAh} \mathrm{g}^{-1}\right)$ ); (iii) surface coating with an ionic conductor or wide-gap oxide [26-29]; (iv) combination of nanocrystallinity and formation of an ordered mesoporous framework [30,31]; and (v) uniform dispersion of highly conductive noble metal or carbon nanotube [32,33].

$\mathrm{LiMn}_{2} \mathrm{O}_{4}$ is a semiconductor with a mixed ionic $\left(10^{-4} \mathrm{~S} \mathrm{~cm}^{-1}\right)$ and electronic $\left(2 \times 10^{-6} \mathrm{~S} \mathrm{~cm}^{-1}\right)$ conductivities [34,35]; however, the deposition of a highly conductive layer should be beneficial. Silver has been utilized as the surface modifier or as a dopant to enhance the performance of electrode materials for LIBs. Ag has the lowest electrical resistivity of $1.6 \times 10^{-8} \Omega \mathrm{cm}$ at room temperature and silver nanoparticles (AgNPs) have unique physical, chemical and electronic properties different from their bulk counterparts [36]. For example, Obrovac et al. [37] showed that the addition of a small amount of Ag can reduce the thickness of solid electrolyte interphase (SEI), which is effective to improve the reversibility of the cells. Despite being a precious metal, AgNPs have been used as additive for many active materials for LIBs, such as $\mathrm{LiCoO}_{2}$ [38], $\mathrm{V}_{2} \mathrm{O}_{5}$ [39], $\mathrm{LiFePO}_{4}$ [40], $\mathrm{MnO}_{2}$ [41] and $\mathrm{Li}_{4} \mathrm{Ti}_{5} \mathrm{O}_{12}$ [42].

Most of the former works on $\mathrm{LiMn}_{2} \mathrm{O}_{4}$ cathode materials modified by silver (doping, coating or $\mathrm{Ag} / \mathrm{LMO}$ composites) were only focused on their electrochemical properties [43-49]. Commonly, the conducting silver coating can be performed by deposition or reduction from $\mathrm{AgNO}_{3}$ suspensions. Features reported in the literature are as follows. Ag/LMO composites with different amounts of $\mathrm{Ag}$ coating (i.e., 3-15 wt.\%) have been synthesized. Son et al. [44] reported the surface modification using 3.3 wt. $\%$ Ag grains with wide particle size distribution (10-100 $\mathrm{nm}$ in diameter). Then, the optimized coating layer provided an initial specific discharge capacity of $\sim 95 \mathrm{mAh} \mathrm{g}^{-1}$ at $2 \mathrm{C}$ rate and displayed a capacity retention of $95 \%$ over 20 cycles. LMO synthesized by ball milling and coated with $6.3 \mathrm{wt} . \%$ $\mathrm{Ag}$ displayed a capacity of $115 \mathrm{mAh} \mathrm{g}{ }^{-1}$ at $10 \mathrm{C}$ [45]. Jiang et al. [48] prepared $\mathrm{Ag} / \mathrm{LiMn}_{2} \mathrm{O}_{4}$ with $5 \mathrm{wt} . \% \mathrm{Ag}$ coating, which consists of homogeneous nanoparticles with the particle sizes of $50-200 \mathrm{~nm}$. Electrochemical studies showed the increase of capacity retention at higher discharge rate after 50 cycles, which is attributed the faster $\mathrm{Mn}^{3+} / \mathrm{Mn}^{4+}$ transition during $\mathrm{Li}^{+}$extraction/insertion than the reaction with $\mathrm{HF}$ alleviating the LMO dissolution in the electrolyte. Zhou et al. [47] examined Ag-modified $\mathrm{LiMn}_{2} \mathrm{O}_{4}$ composites with different $\mathrm{Ag}$ contents (i.e., $0.05-0.3 \mathrm{Ag} / \mathrm{LMO}$ mole ratio) prepared by thermal decomposition of $\mathrm{AgNO}_{3}$. The best battery performance was obtained with $5.9 \mathrm{wt} . \% \mathrm{Ag}$ but the $\mathrm{Ag}$ coating was not evaluated. Huang et al. [45] prepared Ag/LMO composite using high silver content (6.3 wt.\%) but did not characterize this material. However, the improved electrochemical performance (i.e., discharge capacity of $103 \mathrm{mAh} \mathrm{g}^{-1}$ at $10 \mathrm{C}$ rate after 50 cycles) was attributed to the homogeneous dispersion of the nano-sized Ag particles. Wu et al. [46] prepared Ag-modified (8 wt.\%) LMO thin films derived from solution deposition, which are composites of $\mathrm{LiMn}_{2} \mathrm{O}_{4}$ and $\mathrm{Ag}$ particles (agglomerates of $0.1-0.2 \mu \mathrm{m}$ ) non-homogeneously dispersed on the surface. Specific capacity of $42 \mu \mathrm{Ah} \mathrm{cm}{ }^{-2} \mu \mathrm{m}^{-1}$ was obtained at $100 \mu \mathrm{A} \mathrm{cm}{ }^{-2}$ current density. Tay et al. [49] reported the synthesis of $\mathrm{Ag} / \mathrm{LiMn}_{2} \mathrm{O}_{4}$ 
composite, but, despite their claim, electrochemical tests upon cycling are missing. Table 1 summarizes the characterization techniques used in the literature, which shows the scarcity of investigations and demonstrates the advances in the present work thus far.

Table 1. List of investigations carried out on Ag-coated LMO cathode materials from the literature.

\begin{tabular}{cccc}
\hline $\begin{array}{c}\text { Ag Content } \\
\text { (wt. } \%)\end{array}$ & Physical Characterization & Electrochemical Tests & Ref. \\
\hline 3.2 & SEM, EDX & GCD, LTC (20 cycles) & {$[43,44]$} \\
6.3 & XRD, SEM & CV, GCD, EIS, LTC (50cycles) & {$[45]$} \\
n/a & XRD, SEM, impedance & GCD, LTC (50 cycles) & {$[46]$} \\
$3-15$ & XRD, SEM, EDX & CV, GCD, LTC (40 cycles), EIS & {$[47]$} \\
5 & XRD, SEM, EDX & CV, GCD, LTC (100 cycles), EIS & {$[48]$} \\
5.9 & XRD, SEM, impedance & none & {$[49]$} \\
3 & XRD, Rietveld, EDX, XPS, & CV, GCD, LTC (90cycles), IC, & This work \\
& Raman, BET, HRTEM & EIS, diffusion, ASI & \\
\hline
\end{tabular}

From this literature survey, it is obvious that characterizations of $\mathrm{Ag} / \mathrm{LMO}$ are rather scant without complete analysis of the surface of LMO particles. Moreover, most works show limited electrochemical tests to galvanostatic charge-discharge. In some work, Ag particles are covering only secondary particles (agglomerates) instead of primary ones, which was due to the rapid process of reduction of silver. In addition, the structural description of the coating layer and the influence of the oxidation of AgNPs in contact with air were never reported. This study focused on the impact of the procedure used for the thermal treatment of the $\mathrm{Ag} / \mathrm{LMO}$ composites. The research strategy is an increase the rate capability and cycling life of LMO cathode, which involve better electrical contact between particles for driving electrons toward the current collector and protective layer against side reactions with electrolyte. Thus, surface modification using the combination of metallic nanoparticles and protective oxide thin film is welcome. We believe that the examination of the nature and the morphology is of great fundamental and technological relevance because the association of metallic silver nanoparticles with a thin silver oxide layer provides both requested effects.

As far as we know, there is no study reporting the influence of silver deposition and treatment on the structural and electrochemical properties of LMO and its performance as a cathode material for lithium-ion battery [50]. Therefore, more investigations on the properties of Ag/LMO composites are needed because silver can form thermodynamically stable oxides such as $\mathrm{Ag}_{2} \mathrm{O}$ and $\mathrm{AgO}$ when exposed to oxygen [51,52]. $\mathrm{Ag}_{2} \mathrm{O}$ is a p-type semiconductor with a band gap of $\sim 2.3 \mathrm{eV}$ and exhibits a very high electrical resistivity of $\sim 10^{8} \Omega \mathrm{cm}$ [53]. AgO is a semiconductor with a poor electrical conductivity. Raju et al. [54] reported a room temperature conductivity of $\sim 10^{-5} \mathrm{~S} \mathrm{~cm}^{-1}$ with activation energy of $0.64 \mathrm{eV}$ for $\mathrm{AgO}$ thin films (120-nm grain size) deposited by pulsed laser deposition. As there is a big difference in the electrical properties of these oxides, the electrochemical behavior of Ag/LMO composites is expected to be dissimilar.

In this study, Ag/LMO composites with good crystalline structure were prepared by coating of silver on surface of $\mathrm{LiMn}_{2} \mathrm{O}_{4}$ nanoparticles using a facile, cost-effective, scalable and convenient method. We used a co-precipitation synthesis process assisted by oxalic acid to obtain homogeneously distributed powders and calcined the Ag-coated samples in two different atmospheres: vacuum and air ambient. We investigated the nature of the Ag coating and its effect on electrochemical properties of the Ag/LMO cathode materials. Characterizations include X-ray diffraction (XRD), Rietveld refinements, Brunauer-Emmett-Teller (BET) specific surface, pore size and distribution, Raman spectroscopy, X-ray photoelectron spectroscopy (XPS), high-resolution transmission electron microscopy (HRTEM), galvanostatic charge-discharge (GCD), long-term cycling (LTC), electrochemical impedance spectroscopy (EIS) and area-specific impedance (ASI). Promising results in terms of higher surface area, better electrical conductivity and optimized electrochemical performance are 
demonstrated for $\mathrm{Ag} / \mathrm{LiMn}{ }_{2} \mathrm{O}_{4}$ composite calcined in vacuum due to the high concentration of metallic Ag nanospheres and a negligible but useful fraction of insulating AgO covering the spinel electrode.

\section{Materials and Methods}

\subsection{Synthesis}

Spinel $\mathrm{LiMn}_{2} \mathrm{O}_{4}$ materials were prepared by one-pot, two-step precipitation method using a precipitating agent as reported elsewhere [9]. Briefly, predetermined stoichiometric amounts of lithium acetate (Analytical grade, Sd Fine-Chem Ltd., Mumbai, India) and manganese acetate (Analytical grade, 99.99\%, Sigma-Aldrich, Taufkirchen, Germany) with molar ratio Li:Mn = 1:2 were dissolved in separate beakers and stirred in de-ionized (DI) water as aqueous solutions immersed individually in cold water bath. Then, oxalic acid acting as precipitating agent (puriss p.a., anhydrous, $\geq 99.0 \%$, Sigma-Aldrich, Taufkirchen, Germany) with molar ratio 1:1 of the precipitating agent to each metal cation was calculated and dropwise added to the above cold suspension in its beaker individually to precipitate manganese acetate into manganese oxalate and lithium acetate into lithium oxalate. Then, each suspension was stirred for $0.5 \mathrm{~h}$ separately and finally after the precipitation mixed together. The entire precipitate was stirred at $80^{\circ} \mathrm{C}$ to evaporate the water. After obtaining a viscous precipitate, it was poured into a large Petri dish to enhance the rate of evaporation in a wide area. The precipitate was collected and dried at ca. $100{ }^{\circ} \mathrm{C}$ overnight. The calcination was performed in air at 450 and then at $750{ }^{\circ} \mathrm{C}$ for $5 \mathrm{~h}$ for each temperature with intermittent grinding. Finally, the powder was treated in air at $900{ }^{\circ} \mathrm{C}$ for $10 \mathrm{~h}$ (hereafter referred to as LMO). The surface modification of $\mathrm{LiMn}_{2} \mathrm{O}_{4}$ particles was performed by in situ coating technique using an ethanolic silver-nitrate solution. The schematic representation of the Ag coating process is shown in Figure 1.

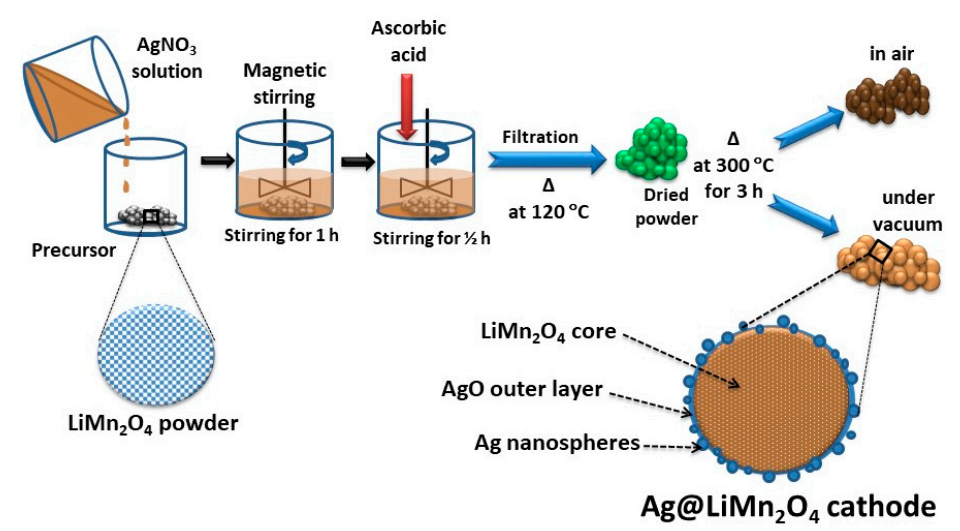

Figure 1. Schematic representation of the $\mathrm{Ag}$ coating process of $\mathrm{LiMn}_{2} \mathrm{O}_{4}$ nanoparticles.

For this process, the Ag: $\mathrm{LiMn}_{2} \mathrm{O}_{4}$ ratio of 3:95 in weight was chosen. Each powder was dissolved separately in absolute alcohol. The calculated weight of silver nitrate was dropwise added to $\mathrm{LiMn}_{2} \mathrm{O}_{4}$ solution. The mixture was stirred for $1 \mathrm{~h}$, and then the reduction of $\mathrm{Ag}^{+}$ions to metallic $\mathrm{Ag}^{0}$ was obtained with ascorbic acid according to the relation:

$$
\mathrm{C}_{6} \mathrm{H}_{8} \mathrm{O}_{6}+2 \mathrm{AgNO}_{3} \rightarrow 2 \mathrm{Ag}+2 \mathrm{HNO}_{3}+\mathrm{C}_{6} \mathrm{H}_{6} \mathrm{O}_{6} .
$$

After stirring the mixture for $30 \mathrm{~min}$, a "silver mirror-like" appearance was observed clearly on the wall of the vessel as an indicator of the formation of Ag nanoparticles. The final mixture was filtrated using very fine filter paper and washed by ethanol. The resulted precursor was divided into two parts. The first part was calcined at $300^{\circ} \mathrm{C}$ for $3 \mathrm{~h}$ in air (labeled as $\mathrm{Ag} / \mathrm{LMO}(\mathrm{a})$ ), while the second part was calcined at $300^{\circ} \mathrm{C}$ for $3 \mathrm{~h}$ under vacuum (named as $\mathrm{Ag} / \mathrm{LMO}(\mathrm{v})$ ). 


\subsection{Characterization}

The crystal structure of the samples and phase identification were examined by $X$-ray diffractometer using a Philips X'Pert apparatus equipped with a CuK $\alpha$ X-ray source $(\lambda=1.54056 \AA)$. Data were collected in the $2 \theta$ range of $10-80^{\circ}$ at a step size of $0.05^{\circ}$. The obtained XRD patterns were refined using the FULLPROF software (Toolbar Fullprof suit program (3.00), version June-2015) [55]. Elemental composition was examined with energy dispersive X-ray (EDX) spectroscopy (Oxford instrument INCA attached to the scanning electron microscope) and with X-ray photoelectron spectroscopy using an ESCALAB 250Xi apparatus (Thermo Fisher Scientific, Les Ulis, France) equipped with $\mathrm{Mg} \mathrm{K}_{\alpha}$ source $(\lambda=1253.6 \mathrm{eV})$. BET surface area and pore size distribution of synthesized samples were determined from $\mathrm{N}_{2}$-adsorption experiments using (Belsorp max version 2.3.2). The BET surface area was calculated from the isotherms in the range from 0.02 to 0.4 of relative pressures $\left(\mathrm{P} / \mathrm{P}_{0}\right)$. Raman spectra were collected with a micro-Raman spectrometer (model Alpha3000 R/AS from Witech, Ulm, Germany) using the laser excitation wavelength $\lambda=532 \mathrm{~nm}$. A silicon crystal was used as a reference for the wavenumber calibration regularly verified with the phonon peak at $520 \mathrm{~cm}^{-1}$. HRTEM images were obtained with a JEOL 2100F microscope operated at $200 \mathrm{kV}$ and equipped with a Cs corrector to achieve atomic resolution better than $0.14 \mathrm{~nm}$.

Cathode electrodes for electrochemical testing were prepared by casting a slurry with a composition of $80 \mathrm{wt} . \% \mathrm{LiMn}_{2} \mathrm{O}_{4}$ active material, $10 \mathrm{wt} . \%$ carbon black Super P or C65 (TIMCAL) and $10 \mathrm{wt} . \%$ polyvinylidene fluorite (PVdF) onto $\mathrm{Al}$ foil. The size of electrode discs is $\emptyset 12 \mathrm{~mm}$ and the mass loading of active material is in the range $1.2-1.3 \mathrm{mg} \mathrm{cm}^{-2}$. These electrodes were assembled inside 2016-type coin cells with lithium metal foil as counter electrode and $1 \mathrm{~mol} \mathrm{~L}^{-1} \mathrm{LiPF}_{6}$ in 1:1 ethylene carbonate: dimethyl carbonate (EC:DMC) as electrolyte. The cyclic voltammetry tests were recorded at a scan rate of $0.2 \mathrm{mV} \mathrm{s}^{-1}$. The cells were galvanostatically charged and discharged at various current densities ( $0.148 \mathrm{~A} \mathrm{~g}^{-1}$ is equivalent to $1 \mathrm{C}$ rate) using a Maccor series 4000 battery tester (Maccor Inc., Tulsa, OK, USA) between 4.5 and $3.0 \mathrm{~V}$ at $20^{\circ} \mathrm{C}$. The potentials reported in this work refer to the $\mathrm{Li}^{\mid} \mid \mathrm{Li}^{+}$ couple. EIS experiments were carried out in the frequency range from $0.1 \mathrm{~Hz}$ to $100 \mathrm{kHz}$ with a bias voltage of $10 \mathrm{mV}$.

\section{Results}

\subsection{Structural Analysis}

The X-ray diffraction (XRD) diagrams of parent $\mathrm{LiMn}_{2} \mathrm{O}_{4}$ and $\mathrm{Ag} / \mathrm{LiMn}_{2} \mathrm{O}_{4}$ composites are shown in Figure 2. All patterns display well-resolved reflections with very smooth background indicating the high crystallinity of LMO materials prepared by precipitation method. All the reflections for samples with or without surface treatment are indexed to the characteristic Bragg lines of the spinel $\mathrm{LiMn}_{2} \mathrm{O}_{4}$ ( $F d-3 m$ space group, JCPDS card No. 89-1026) without any residual impurities such as Mn-based oxides. The cubic structure of $\mathrm{LiMn}_{2} \mathrm{O}_{4}$ (Figure 2b) can be represented by an assembly of $\mathrm{LiO}_{4}$ tetrahedra and $\mathrm{MnO}_{6}$ octahedra, in which $\mathrm{Li}$ atoms occupy the $8 a$ Wyckoff positions and Mn atoms the $16 d$ sites. The slight broadening of the XRD reflections indicates that the material is of nanoscale character and agrees well with previous $\mathrm{LiMn}_{2} \mathrm{O}_{4}$ reports [31,56]. In the XRD patterns of $\mathrm{Ag} / \mathrm{LMO}(\mathrm{a})$ and $\mathrm{Ag} / \mathrm{LMO}(\mathrm{v})$ samples, it is difficult to clearly identify the characteristic peaks of $\mathrm{Ag}$ (i.e., cubic (fcc) phase, (111)-reflection at $2 \theta=38.12^{\circ}$ ) and/or its oxides (i.e., cubic $\mathrm{Ag}_{2} \mathrm{O}$ phase, (111)-reflection at $2 \theta=32.85^{\circ}$; monoclinic $\mathrm{AgO}$ phase, (111)-reflection at $2 \theta=37.23^{\circ}$ ) because the small amount of the $\mathrm{Ag}$ additives and the overlapping of reflection peaks with those of $\mathrm{LiMn}_{2} \mathrm{O}_{4}$. Nevertheless, to distinguish the slight modifications (if exist), several structural parameters are worth considering. First, as reported by several workers, the small value of the full-width at half-maximum (FWHM) of the (400) peak located at $2 \theta=43.95^{\circ}$ is related to higher crystallinity and better ordering of local structure [57-59]. Note that all relative peak intensities of reflection lines match well with the values given by the JCPDS card No. 89-1026. 
In our experiments, some reflections for $\mathrm{Ag} / \mathrm{LMO}(\mathrm{v})$ sample are broader than for the pristine one, indicating that the (111), (200) and (220) peaks of metallic Ag almost overlap the (222), (400) and (440) peaks of LMO. Second, we found that the peak intensity ratio of the (311)/(400) reflections is slightly smaller for the Ag-coated LMO samples (0.88) than for the pristine sample (0.91). Since the doping could increase the peak intensity ratio of $I_{(311)} / I_{(400)}[23,24]$, it suggests that silver does not penetrate the spinel lattice but remains at the surface. The structural evolution of the $\mathrm{LiMn}_{2} \mathrm{O}_{4}$ spinel coated with Ag were analyzed using the Rietveld refinement. The refinement parameters are listed in Table 2 and the refined XRD patterns are displayed in Figure 3a-c.

A good agreement between calculated diagrams and observed patterns was obtained assuming the composition of $\mathrm{Ag} / \mathrm{LMO}$ composites including a $\mathrm{LiMn}_{2} \mathrm{O}_{4}$ spinel core ( $F d-3 m$ S.G.) with metallic Ag nanoparticles ( $F m 3 m$ S.G) and a layer of silver oxide $\left(P 2_{1} / c\right.$ S.G.) at the surface. In the XRD analysis, the phase fraction was refined with uncertainty of $0.1 \%$ and refined by minimization of the difference between experimental and calculated diffractogram. The best results were obtained with reliability factors of $\sim 8 \%$. Value of the cubic lattice parameter $a=8.240(1) \AA$ for $\mathrm{LiMn}_{2} \mathrm{O}_{4}$ does not vary significantly for $\mathrm{Ag} / \mathrm{LMO}$ composites, demonstrating the thermodynamic stability of the spinel upon $\mathrm{Ag}$ coating. These results show that $\mathrm{Ag}^{+}$with an ionic radius of $1.26 \AA$, much bigger than that of $\mathrm{Mn}^{3+}$ $(0.645 \AA)$, is not hosted by the spinel lattice, in good agreement with former reports [46-48].
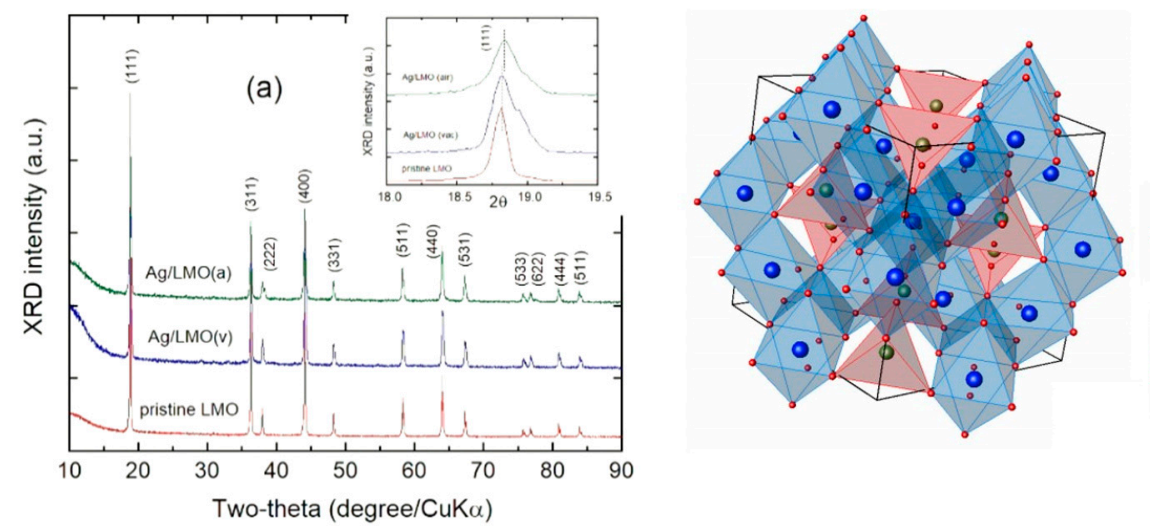

(b) $\mathrm{LiO}_{4}$

Figure 2. (a) XRD patterns of pristine, $\mathrm{Ag} / \mathrm{LMO}(\mathrm{a})$ and $\mathrm{Ag} / \mathrm{LMO}(\mathrm{v})$ samples recorded with $\mathrm{CuK} \alpha \mathrm{XRD}$ source. Inset shows the detailed (111) reflection. (b) Sketch of the crystal structure of $\mathrm{LiMn}_{2} \mathrm{O}_{4}$.

Table 2. Results of Rietveld refinements for pristine and Ag-modified $\mathrm{LiMn}_{2} \mathrm{O}_{4}$. The phase fraction was refined with uncertainty of $0.1 \%$.

\begin{tabular}{lccc}
\hline Crystal Data & Pristine LMO & Ag/LMO(a) & Ag/LMO(v) \\
\hline Lattice parameters & & & \\
$a(\AA)$ & $8.240(1)$ & $8.248(1)$ & $8.238(9)$ \\
$V\left(\AA^{3}\right)$ & 559.5 & 561.1 & 559.3 \\
$I_{(311)} / I_{(400)}$ & 0.91 & 0.88 & 0.88 \\
$\mathrm{FWHM}(400)$ & 0.233 & 0.276 & 0.302 \\
$L_{c}(\mathrm{~nm})$ & 72.7 & 83.4 & 69.4 \\
$e \times 10^{-3}(\mathrm{rd})$ & 1.5 & 2.2 & 1.6 \\
\hline Reliability factors & & & \\
$R_{p}(\%)$ & 8 & 8.1 & 9.2 \\
$R_{w}(\%)$ & 6.1 & 7.7 & 8.1 \\
$R_{\exp }$ & 10.9 & 11.1 & 13.9 \\
$c^{2}$ & 1.48 & 2.26 & 1.93 \\
\hline $\mathrm{Material}$ fraction $(\mathrm{mol} \%)$ & & & \\
$\mathrm{LiMn} \mathrm{O}_{4}$ & 100 & 96.7 & 96.6 \\
$\mathrm{Ag}$ & 0 & 0.2 & 2.6 \\
$\mathrm{AgO}$ & 0 & 3.1 & 0.8 \\
\hline
\end{tabular}


Values of the coherence $\left(L_{c}\right)$ lengths determined from the Scherrer's formula are in the range $69 \leq L_{\mathrm{c}} \leq 84 \mathrm{~nm}$. Almost identical $L_{\mathrm{c}}$ values evidence that the $\mathrm{LiMn}_{2} \mathrm{O}_{4}$ framework is well preserved after coating by Ag. The phase fraction in $\mathrm{Ag} / \mathrm{LMO}$ is also determined from Rietveld analysis using the model of $\mathrm{Ag}$ nanoparticles and $\mathrm{AgO}$ coating layer deposited on the surface of $\mathrm{LiMn}_{2} \mathrm{O}_{4}$ particles. Results reported in Table 2 show that the $\mathrm{Ag} / \mathrm{LMO}(\mathrm{v})$ sample contains $2.6 \%$ metallic $\mathrm{Ag}$ and $0.8 \%$ $\mathrm{AgO}$ phase. In contract, the sample heat treated in air has a high content of $\mathrm{AgO}(3.2 \%)$, which is an insulating matrix produced by the oxidation of Ag nanoparticles.
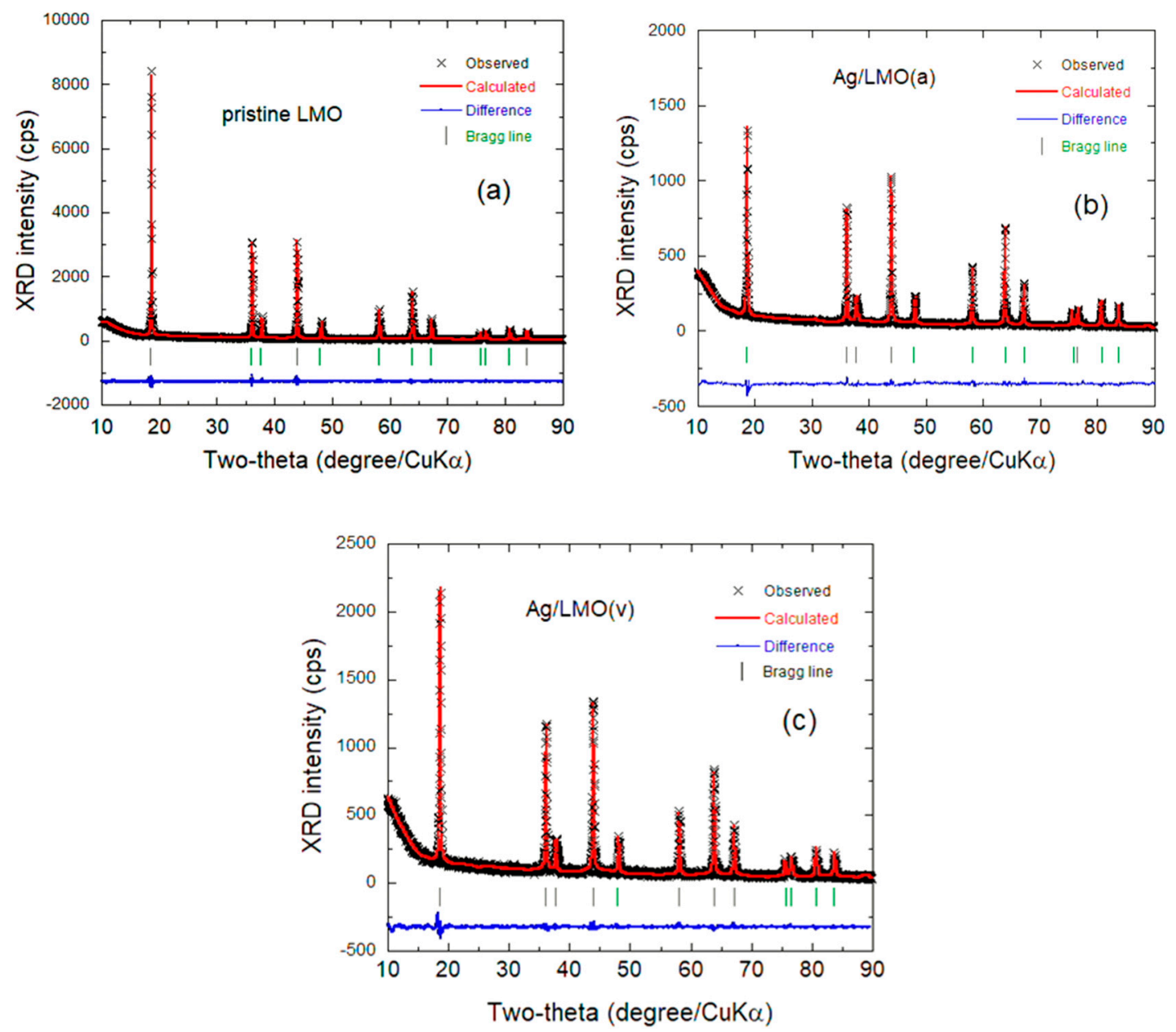

Figure 3. Rietveld refinements of XRD patterns of: as-prepared pristine LMO (a); Ag/LMO treated in air (b); and Ag/LMO calcined in vacuum (c).

The microstrain $(\varepsilon)$ of the LMO particles was determined using the Williamson-Hall equation [60]:

$$
B_{h k l} \cos \theta_{h k l}=\left(K \lambda / L_{\mathrm{c}}\right)+4 \varepsilon \sin \theta_{\mathrm{hkl}}
$$

where $B_{\mathrm{hkl}}$ is the line broadening of a Bragg reflection $(h k l), K$ is the shape factor and $L_{\mathrm{c}}$ is the effective crystallite size and $\lambda$ is the $X$-ray wavelength. The microstrain is estimated from the slope of the plot $B_{h k l} \cos \theta_{h k l}$ as a function of $4 \sin \theta_{h k l}$ and the intersection with the vertical axis provide the crystallite size. The $B_{h k l}$ value used here is the instrumental corrected one. In Figure 4, we observe that the microstrain of $1.6 \times 10^{-3} \mathrm{rd}$ for $\mathrm{Ag} / \mathrm{LMO}(\mathrm{v})$ is almost similar to that of pristine $\mathrm{LMO}\left(1.5 \times 10^{-3} \mathrm{rd}\right)$, which indicates that the formation of Ag nanoparticles does not influence the underlying LMO lattice. In contrast, the microstrain for the $\mathrm{Ag} / \mathrm{LMO}(\mathrm{a})$ sample increases considerably to $2.2 \times 10^{-3} \mathrm{rd}$, indicating the difference of morphology in the coating layer that created a local deformation of the structure. 


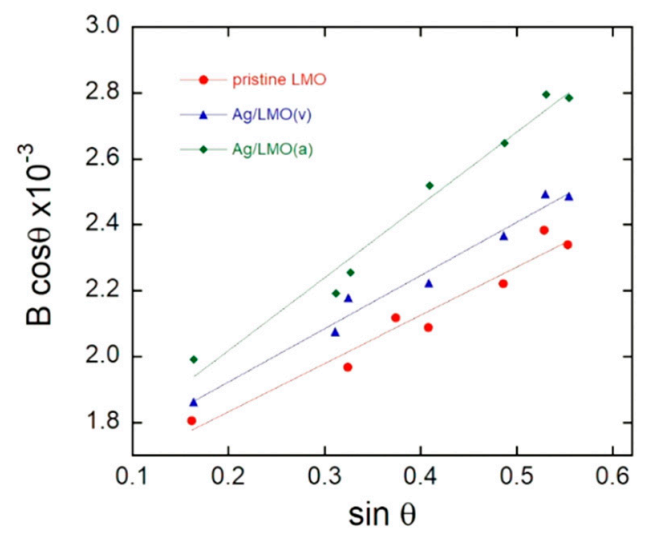

Figure 4. Determination of the microstrain $\varepsilon$ from the full-width at half-maximum, $B_{\mathrm{hkl}}$, of XRD peaks according to Equation (1).

The chemical composition of Ag/LMO powders was analyzed by EDX spectroscopy (Figure 5). The spectrum of the $\mathrm{Ag} / \mathrm{LMO}(\mathrm{v})$ sample shows only the additional peak of $\mathrm{Ag}$ and the C-peak that originates from the carbon foil used for this experiment. The concentration of the different elements deduced from the EDX spectrum (Ag fraction of $2.85 \mathrm{wt} . \%$ ) is consistent with results from Rietveld refinements (Ag fraction of 3.3-3.4\%).

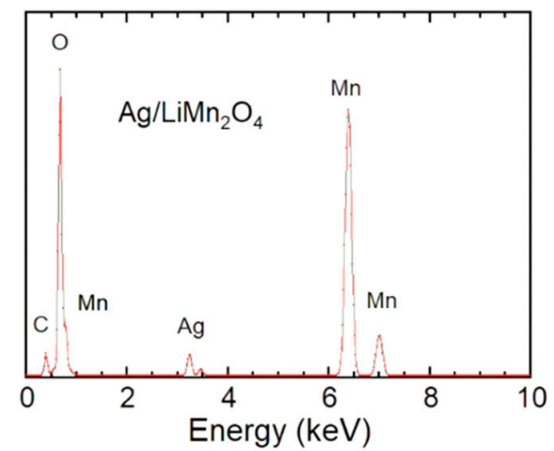

Figure 5. EDX spectrum of the $\mathrm{Ag} / \mathrm{LMO}(\mathrm{v})$ sample.

\subsection{Surface Analysis}

The surface of LMO particles was investigated by XPS, BET surface area, pore-size measurements and Raman spectroscopy. XPS measurements were carried out to evaluate the chemical composition and characterize the chemical state of cations in LMO samples. The spectra are shown in Figure 6 and the binding energy of $\mathrm{Mn} 2 \mathrm{p}_{3 / 2}, \mathrm{O} 1 \mathrm{~s}$ and $\mathrm{Ag} 3 \mathrm{~d}_{5 / 2}$ core levels are listed in Table 3 . Both the line shape (Gaussian-like) and the binding energy of O 1s (530.1 eV), Li 1s (55.0 eV) and Mn 2p $\mathrm{p}_{3 / 2}(642.2 \mathrm{eV})$ match well with the characteristics XPS patterns of the $\mathrm{LiMn}_{2} \mathrm{O}_{4}$ spinel phase [61,62]. As shown in Figure $6 \mathrm{~b}-\mathrm{d}$, the Mn $2 \mathrm{p}_{3 / 2}$ and Mn 2p $\mathrm{p}_{1 / 2}$ XPS patterns of Mn $2 \mathrm{p}$ (with a peak separation of $11.7 \mathrm{eV}$ ) can be fitted in two bands using the binding position of $\mathrm{Mn}^{3+}$ and $\mathrm{Mn}^{4+}$ cations. The average valence state of $\mathrm{Mn}$ was found to be 3.504, 3.507 and 3.505 in pristine $\mathrm{LiMn}_{2} \mathrm{O}_{4}, \mathrm{Ag} / \mathrm{LMO}(\mathrm{a})$ and $\mathrm{Ag} / \mathrm{LMO}(\mathrm{v})$, respectively, which confirms the stoichiometry of the sample.

Table 3. XPS analysis of pristine $\mathrm{LMO}$ and Ag/LMO composites.

\begin{tabular}{|c|c|c|c|c|}
\hline \multirow{2}{*}{ Sample } & \multicolumn{3}{|c|}{ Binding Energy (eV) } & \multirow{2}{*}{$\begin{array}{l}\text { Average Mn } \\
\text { Valence State }\end{array}$} \\
\hline & $\operatorname{Mn} 2 p_{3 / 2}$ & O 1s & $\operatorname{Ag} 3 d_{5 / 2}$ & \\
\hline Pristine LMO & 642.2 & 530.1 & - & 3.504 \\
\hline $\mathrm{Ag} / \mathrm{LMO}(\mathrm{v})$ & 642.2 & 530.1 & 367.8 & 3.507 \\
\hline $\mathrm{Ag} / \mathrm{LMO}(\mathrm{a})$ & 642.2 & 530.1 & 367.6 & 3.505 \\
\hline
\end{tabular}



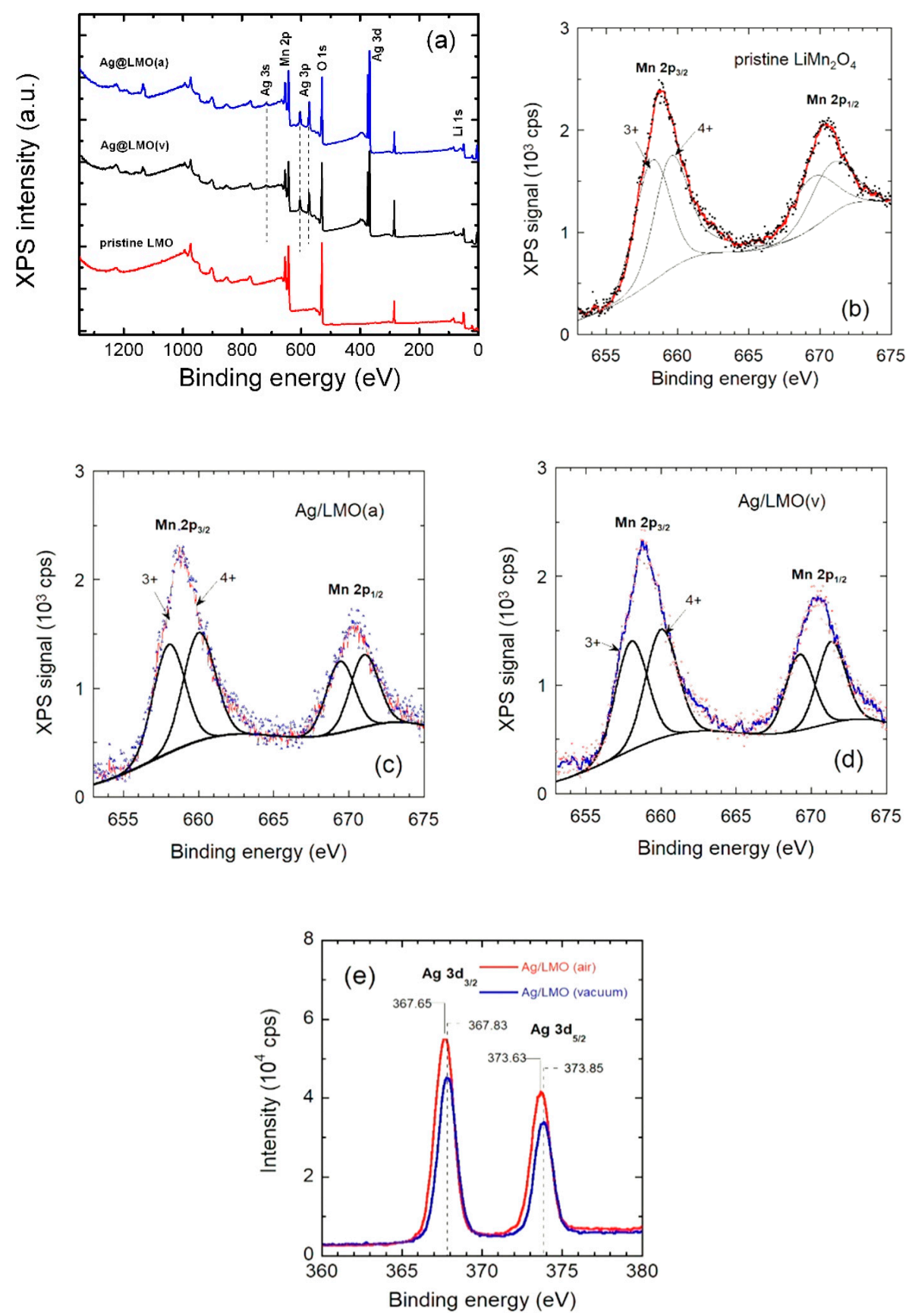

Figure 6. (a) XPS survey spectra. High-resolution XPS spectrum of Mn 2p core level of: (b) pristine $\mathrm{LMO}$; (c) Ag/LMO(a); and (d) Ag/LMO(v). (e) High-resolution XPS spectrum of Ag 3d core level of $\mathrm{Ag} / \mathrm{LMO}(\mathrm{a})$ and $\mathrm{Ag} / \mathrm{LMO}(\mathrm{v})$ samples.

The XPS spectra of Ag-modified LMO samples show additional peaks attributed to the Ag 3d, $\mathrm{Ag} 3 \mathrm{p}$ and Ag 3s core levels. The high-resolution XPS patterns of Ag 3d core level shown in the spectral region 360-380 eV distinguish the different natures of silver in $\mathrm{Ag} / \mathrm{LMO}(\mathrm{v})$ and $\mathrm{Ag} / \mathrm{LMO}(\mathrm{a})$ composites (Figure 6e). In the spectrum of $\mathrm{Ag} / \mathrm{LMO}(\mathrm{v})$, the $\mathrm{Ag} 3 \mathrm{~d}_{5 / 2}$ peak position at $367.8 \mathrm{eV}$ and the $3 \mathrm{~d}_{\text {-peak }}$ splitting of $6.0 \mathrm{eV}$ corresponds to that of $\mathrm{Ag}^{0}$ [63], whereas the shift of the $3 \mathrm{~d}$ peak toward lower energies in the spectrum of $\mathrm{Ag} / \mathrm{LMO}(\mathrm{a})$ indicate the presence of $\mathrm{AgO}$ [64].

As expected, the oxidation of silver results in a shift of the $3 d_{5 / 2}$ core level to higher binding energy: the peak is located at $368.2 \mathrm{eV}$ in metallic silver vs. $368.6 \mathrm{eV}$ in $\mathrm{AgO}$ [65]. However, here, the peak for $\mathrm{Ag}^{0}$ was found at a higher energy $(368.8 \mathrm{eV})$. The shift of binding energy of $\mathrm{Ag} 3 \mathrm{~d}$ states is attributed 
to the presence of $\mathrm{Ag}^{0}$ nanoparticles instead of a continuous $\mathrm{Ag}$ surface. This effect has been reported several times [66-68]: the authors reported that the shift to higher binding energy increases with decreasing nanoparticle diameter. For example, Lopez-Salido et al. [66] observed a positive core level shift for Ag nanoparticles deposited on highly ordered pyrolytic graphite (HOPG) surfaces. Similarly, Tanaka et al. [68] carried out XPS studies of Au nanoparticles supported on HOPG substrates and attributed these energy shifts to the dynamic final-state effect on the metal Au core-level photoemission due to the positive charge with a finite lifetime left behind in the nanoparticles in the photoemission final state.

The surface area of an electrochemically active material is an important parameter for the determination of the exchange-current at the electrolyte-electrode interface and kinetics of $\mathrm{Li}^{+}$ions in electrode. As shown in Table 4, the BET specific surface area of LMO is $2.1 \mathrm{~m}^{2} \mathrm{~g}^{-1}$, which decreases to $0.6 \mathrm{~m}^{2} \mathrm{~g}^{-1}$ for Ag/LMO(a) but increases to $4.1 \mathrm{~m}^{2} \mathrm{~g}^{-1}$ for $\mathrm{Ag} / \mathrm{LMO}(\mathrm{v})$. This result shows the difference in the surface between $\mathrm{Ag} / \mathrm{LMO}$ composites prepared in air or in vacuum. The increase in BET value is attributed to the formation of spherical-like AgNPs on the surface of $\mathrm{LiMn}_{2} \mathrm{O}_{4}$ particles. Such phenomenon has also been observed for $\mathrm{SiO}_{2} / \mathrm{Ag}$ composites [69].

Table 4. BET results and pore structure parameters for pristine $\mathrm{LMO}$ and $\mathrm{Ag} / \mathrm{LMO}$ composites.

\begin{tabular}{cccc}
\hline Sample & $\begin{array}{c}\text { BET Surface Area } \\
\left(\mathbf{m}^{\mathbf{2}} \mathbf{g}^{-\mathbf{1}}\right)\end{array}$ & $\begin{array}{c}\text { Total Pore Volume } \\
\left(\mathbf{c m}^{\mathbf{3}} \mathbf{g}^{\mathbf{- 1}}\right)\end{array}$ & $\begin{array}{c}\text { Mean Pore Diameter } \\
(\mathbf{n m})\end{array}$ \\
\hline $\mathrm{LMO}$ & 2.1 & 0.07 & 5.5 \\
$\mathrm{Ag} / \mathrm{LMO}(\mathrm{a})$ & 0.6 & 0.128 & 22.5 \\
$\mathrm{Ag} / \mathrm{LMO}(\mathrm{v})$ & 4.1 & 0.152 & 22.6 \\
\hline
\end{tabular}

Figure 7a-c shows the typical $\mathrm{N}_{2}$ adsorption-desorption isotherms of the pristine $\mathrm{LMO}, \mathrm{Ag} / \mathrm{LMO}(\mathrm{a})$ and $\mathrm{Ag} / \mathrm{LMO}(\mathrm{v})$, respectively, along with the pore size distribution shown in insets. The isotherm curves of the three samples display hysteresis loops indicating the hierarchical mesoporous structure of LMO nanopowders [31,70]. The shape of the isotherms provides us insights about the porosity of the samples. The height of the plateaus observed at low $(<0.1)$ relative pressures indicates the relative volume of the micropores. The mesopores (10-50 nm in size) correspond to the interconnecting voids existing between randomly packed nanoparticles [70]. For the pristine LMO sample (Figure 7a), the isotherm increases with increasing $P / P_{0}$ and forms a H3-hysteresis loop, for Ag/LMO(a) and $\mathrm{Ag} / \mathrm{LMO}(\mathrm{v})$ samples (Figure $7 \mathrm{~b}, \mathrm{c})$, at relative high pressure $\left(P / P_{0}>0.9\right)$ the isotherm increases rapidly and forms a lag loop, which is, according to IUPAC classification, typical of a H1-hysteresis loop. The reason for this phenomenon may be due to the differences in the accumulation of particles.
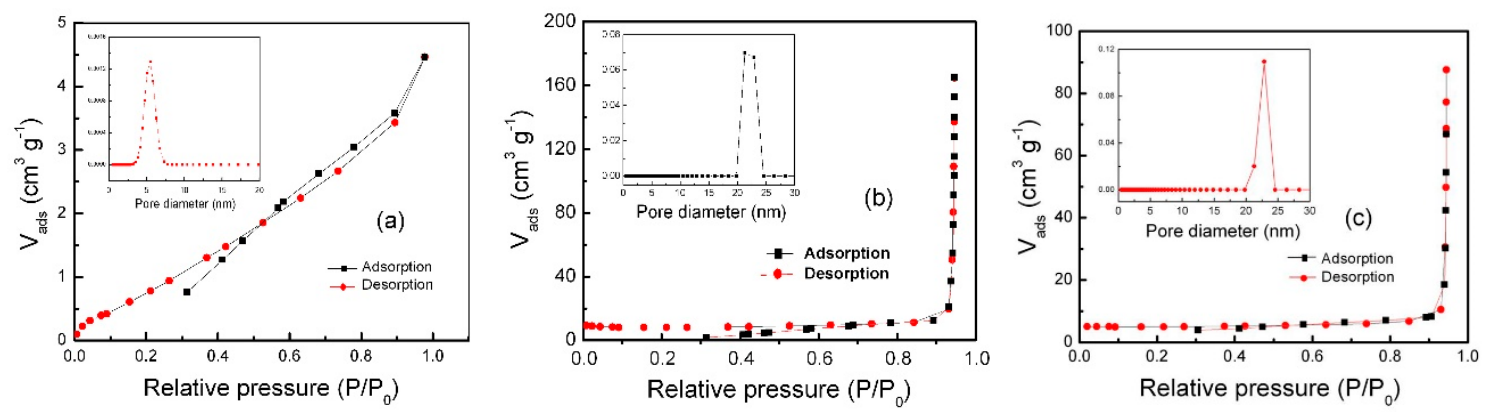

Figure 7. Nitrogen adsorption/desorption isotherms for: (a) pristine LMO; (b) Ag/LMO(a); and (c) $\mathrm{Ag} / \mathrm{LMO}(\mathrm{v})$. The insets show the pore size distribution.

The pore structure was calculated using the Barrett-Joyner-Halenda (BJH) model. As shown in the insets of Figure 7, the $\mathrm{BJH}$ pore size distribution shows that all samples have a mesoporous character and monodisperse mesopore sizes are estimated to be 5.5, 22.5 and $22.6 \mathrm{~nm}$ for pristine LMO, $\mathrm{Ag} / \mathrm{LMO}(\mathrm{a})$ and $\mathrm{Ag} / \mathrm{LMO}(\mathrm{v})$ samples, respectively. It is remarkable that the Ag coating obtained by an 
additional calcination process leads to change in the mesoporous structure of LMO. It is well known that the mesoporosity of electrode material is beneficial for high rate performance in LIBs. The bigger size of mesopores (22.6 vs. 5.5. $\mathrm{nm}$ ) for $\mathrm{Ag} / \mathrm{LMO}$ composites favors the charge transfer across the electrode-electrolyte interface, enhances the ability of large current discharge performance. In addition, the mesopore size uniformly interconnected can decrease the diffusion lengths of approximately $10 \mathrm{~nm}[71]$.

The local structure, i.e., short-range environment within LMO lattice, and surface state of particles were investigated using Raman scattering (RS) spectroscopy in the spectral range $100-800 \mathrm{~cm}^{-1}$. In this region, the internal and external modes of vibration of $\mathrm{LiMn}_{2} \mathrm{O}_{4}$ are observed. Figure $8 \mathrm{a}-\mathrm{c}$ presents the Raman spectra of pristine $\mathrm{LMO}$ and $\mathrm{Ag} / \mathrm{LMO}$ composites, respectively. Considering the cubic $F d-3 m$ structure $\left(\mathrm{O}_{\mathrm{h}}{ }^{7}\right.$ spectroscopic symmetry) for $\mathrm{LiMn}_{2} \mathrm{O}_{4}$, one expects six Raman active modes represented by the species $2 A_{1 \mathrm{~g}}+1 E_{\mathrm{g}}+3 T_{2 \mathrm{~g}}$ [72-74]. A common feature is the presence of the strong band around $600 \mathrm{~cm}^{-1}$ viewed as the symmetric $\mathrm{Mn}-\mathrm{O}$ stretching vibration involving motion of oxygen atoms inside the $\mathrm{MnO}_{6}$ octahedron. The splitting at 572 and $615 \mathrm{~cm}^{-1}$ is due to the presence of regular $\mathrm{Mn}^{\mathrm{IV}} \mathrm{O}_{6}$ and distorted $\mathrm{Mn}^{\mathrm{III}} \mathrm{O}_{6}$ octahedra. The low-frequency peak at $160 \mathrm{~cm}^{-1}$ is assigned to the external mode, i.e., translational $T_{2 \mathrm{~g}}{ }^{(T)}$ mode. The peaks at 342 and $462 \mathrm{~cm}^{-1}$ are attributed to the $E_{\mathrm{g}}$ and $T_{2 \mathrm{~g}}{ }^{(2)}$ modes, respectively, while the high-frequency $T_{2 \mathrm{~g}}{ }^{(3)}$ mode is observed at $653 \mathrm{~cm}^{-1}$. The Raman spectra of Ag-modified LMO display four extra peaks appearing at 390, 435, 494 and $713 \mathrm{~cm}^{-1}$, which are the fingerprints of the presence of the AgO phase ( $P 2_{1} / c$ S.G.) on the LMO surface. Analysis of the $C_{2 \mathrm{~h}}{ }^{5}$ group factor of $\mathrm{AgO}$ monoclinic phase predicts six Raman active modes $\left(3 A_{\mathrm{g}}+3 B_{\mathrm{g}}\right)$. The symmetric stretching $v_{\mathrm{s}}(\mathrm{Ag}-\mathrm{O})$ mode at $494 \mathrm{~cm}^{-1}$ is associated with the motion of oxygen with $\mathrm{Ag}(\mathrm{I})$ cations linearly coordinated, while the peak at $435 \mathrm{~cm}^{-1}$ is assigned to the $v_{\mathrm{s}}(\mathrm{Ag}-\mathrm{O})$ mode for oxygen square-coordinated about $\mathrm{Ag}(\mathrm{III})$. The band at $390 \mathrm{~cm}^{-1}$ corresponds to the symmetric bending $\delta(\mathrm{O}-\mathrm{Ag}-\mathrm{O})$ mode in the AgO lattice $[75,76]$. The high-frequency Raman signal at $713 \mathrm{~cm}^{-1}$ is identified as the vibration of silver carbonate formed by reaction of $\mathrm{Ag}_{2} \mathrm{O}$ with atmospheric $\mathrm{CO}_{2}$ [77].
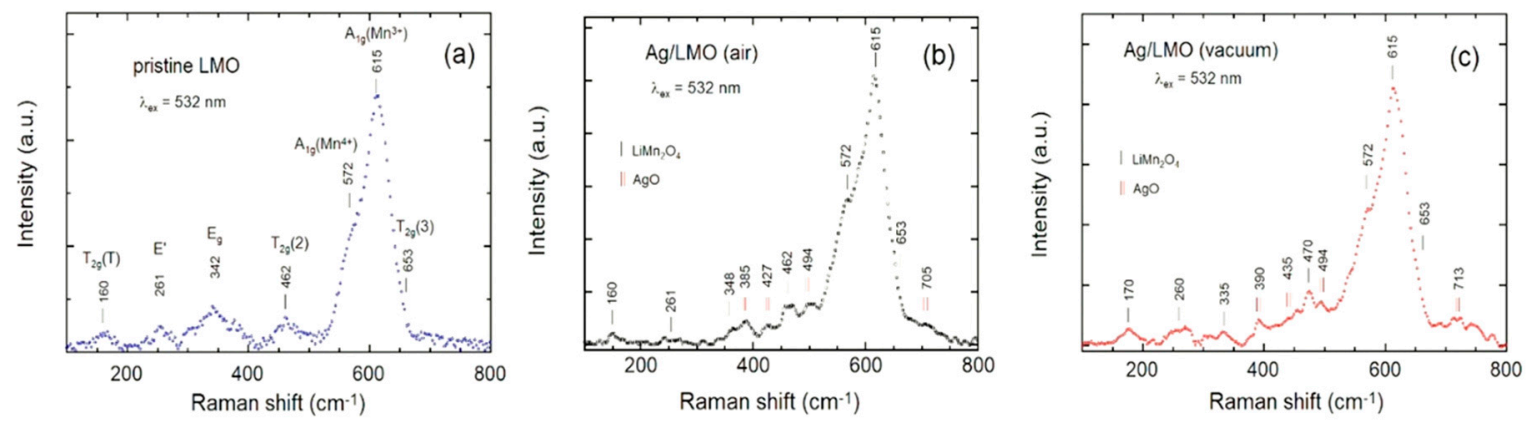

Figure 8. Raman spectra of samples recorded with the laser excitation line at $532 \mathrm{~nm}$ (green light): (a) pristine $\mathrm{LMO}$; (b) $\mathrm{Ag} / \mathrm{LMO}(\mathrm{a})$; and (c) $\mathrm{Ag} / \mathrm{LMO}(\mathrm{v})$.

These results are consistent with those of XPS and XRD from the view point to the prevalence of $\mathrm{Ag}^{0}$ in $\mathrm{Ag} / \mathrm{LMO}(\mathrm{v})$ and $\mathrm{AgO}$ in $\mathrm{Ag} / \mathrm{LMO}(\mathrm{a})$. It is well known that silver and gold nanoparticles, or roughened surfaces of these materials, enhance the Raman signal of molecules near them. The silver and gold themselves are not Raman-active-in other words, what we observe is not the Raman signal of silver-silver bonds but the enhancement of signals from molecules in close proximity, sometimes by many orders of magnitude. However, the signature of $\mathrm{AgO}$ is present in the Raman spectra.

\subsection{Morphology}

The morphology and surface state of as-prepared LMO particles was examined in detail by transmission electron microscopy (TEM). Figure 9 presents the typical TEM and HRTEM Figure for pristine LMO (Figure 9a,b), Ag/LMO(v) (Figure 9c,d) and Ag/LMO(a) (Figure 9e,f) samples with analyses of the lattice fringes and related fast Fourier transform (FFT) patterns. TEM image of pristine LMO (Figure 9a) shows particles $200-400 \mathrm{~nm}$ in size with truncated octahedral shape characteristic 
to $\mathrm{LiMn}_{2} \mathrm{O}_{4}$. HRTEM in Figure $9 \mathrm{~b}$ displays well crystallized nanoparticles with a smooth surface and exhibit lattice fringes with interplanar distance of $0.47 \mathrm{~nm}$ corresponding to the (111) plane of the $\mathrm{LiMn}_{2} \mathrm{O}_{4}$ spinel phase. The related FFT pattern agrees well with the SAED pattern of the whole particle of $\mathrm{LiMn}_{2} \mathrm{O}_{4}$ and reveals its polycrystalline nature.
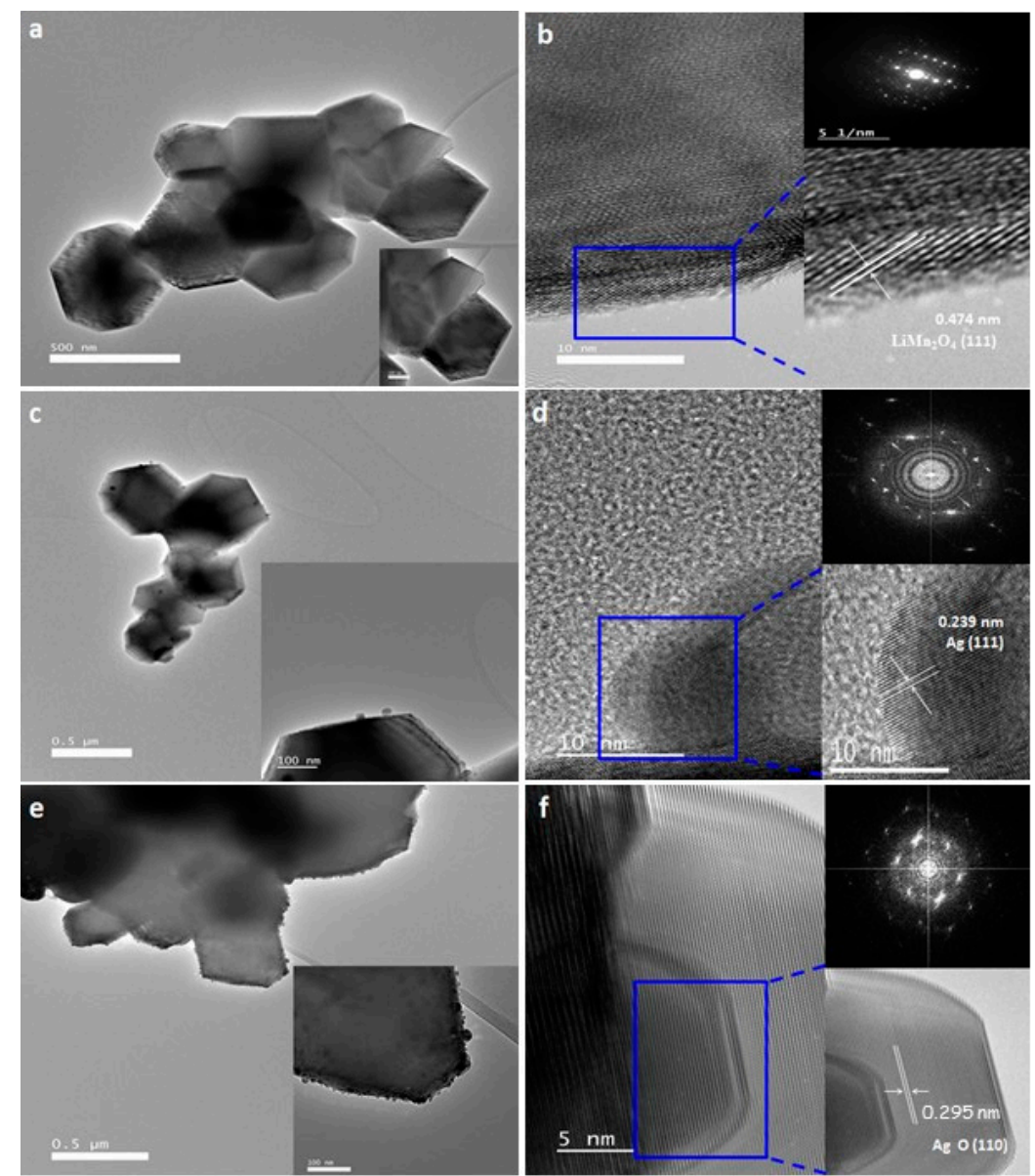

Figure 9. TEM images at different magnifications of: (a,b) pristine LMO; (c,d) Ag/LMO(v); and $(\mathbf{e}, \mathbf{f}) \mathrm{Ag} / \mathrm{LMO}(\mathrm{a})$.

The morphology of $\mathrm{Ag} / \mathrm{LMO}(\mathrm{v})$ nanoparticles is shown in Figure 9c,d. It is obvious that the coating has no effect on the spinel morphology. Only very small quasi-spherical spots of Ag nanoparticles with diameters $8-15 \mathrm{~nm}$ were found to be distributed on the surface of LMO particles. These spots are identified by the appearance of the lattice fringes of $0.239-\mathrm{nm}$ characteristic of the (111) plane of metallic $\mathrm{Ag}^{0}$ [78]. The surface of LMO particles treated in air is modified differently and becomes rough (Figure 9e,f). It could be the reason the air-treated sample shows smaller surface area. The lattice fringes of $0.295 \mathrm{~nm}$ match well with the (110) plane of AgO [79]. These patterns show that the Ag/LMO(a) sample is coated by few $\mathrm{Ag}^{0}$ nanospheres with diameter of $\sim 15 \mathrm{~nm}$ embedded in an $\mathrm{AgO}$ matrix. Thus, most of the silver phase has been oxidized in air to form a relatively thick layer $(\sim 15 \mathrm{~nm})$ of AgO (Figure 9e,f).

\subsection{Electrochemical Properties}

To investigate the effect of $\mathrm{Ag}$ coating on the electrochemical performance of $\mathrm{LiMn}_{2} \mathrm{O}_{4}$, the $\mathrm{LMO} \| \mathrm{Li}$ cells were tested by cyclic voltammetry (CV) and galvanostatic charge-discharge (GCD) measurements using 2016-type coin cells. Experiments were performed with the upper cut-off potential set at $4.5 \mathrm{~V}$ vs. $\mathrm{Li} \mid \mathrm{Li}^{+}$to avoid the cation mixing by the appearance of $\mathrm{Mn}$ in the $8 a$ tetrahedral sites [80]. Figure 10a-c shows the cyclic voltammograms of the LMO samples. 

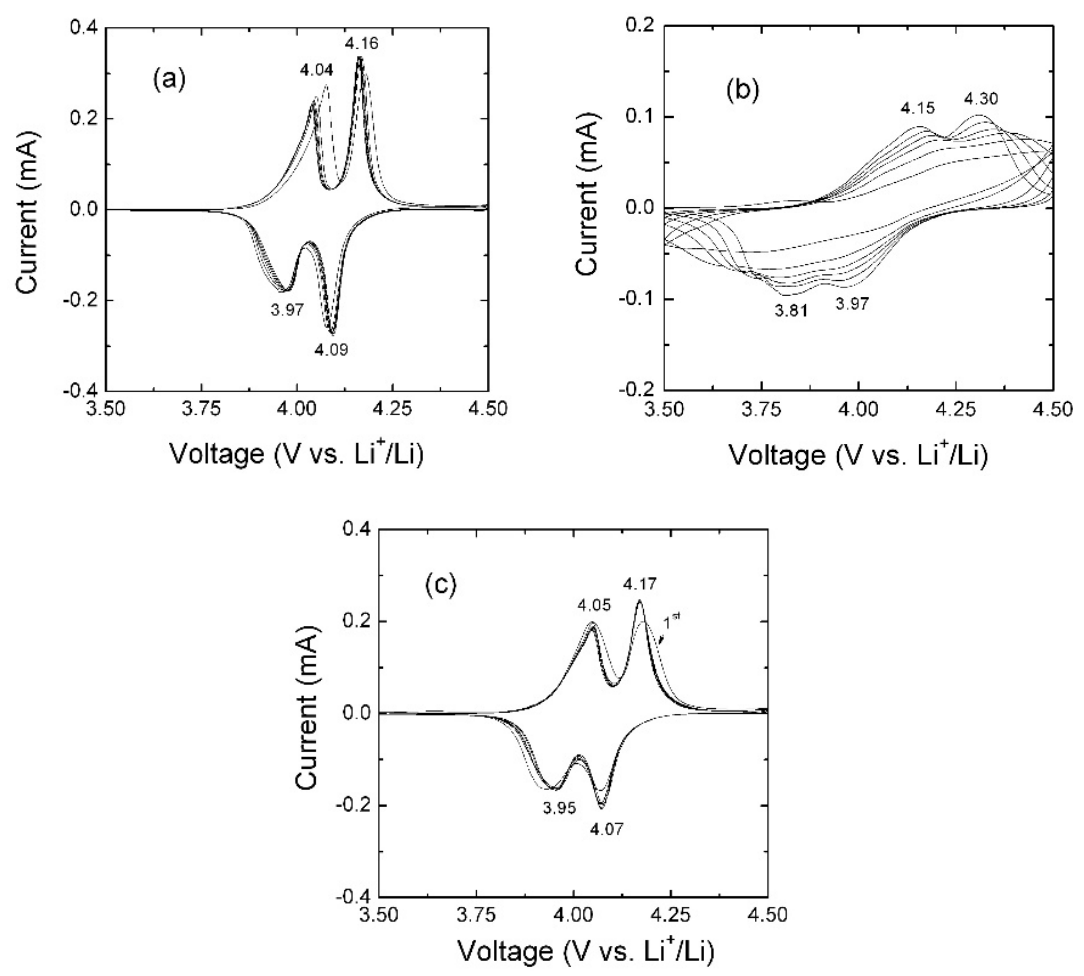

Figure 10. Cyclic voltammograms of samples cycled between 3.5 and $4.5 \mathrm{~V}\left(v \mathrm{~s} . \mathrm{Li}^{2} \mid \mathrm{Li}^{+}\right)$at a scan rate of $0.2 \mathrm{mV} \mathrm{s}^{-1}$ : (a) pristine LMO; (b) $\mathrm{Ag} / \mathrm{LMO}(\mathrm{a})$; and (c) $\mathrm{Ag} / \mathrm{LMO}(\mathrm{v})$.

The CV curves of pristine $\mathrm{LMO}$ and $\mathrm{Ag} / \mathrm{LMO}(\mathrm{v})$ samples (Figure $10 \mathrm{a}, \mathrm{b}$ ) display two sets of well-defined anodic and cathodic peaks characteristic of the redox reaction in the $\mathrm{Li}_{1-\mathrm{x}} \mathrm{Mn}_{2} \mathrm{O}_{4}(0 \leq \mathrm{x} \leq 1)$ spinel phase. The redox peak splitting is associated with the typical two-step reversible extraction and insertion of $\mathrm{Li}^{+}$ion from/into the $\mathrm{LiMn}_{2} \mathrm{O}_{4}$ framework [81-85]. The first set at 4.075/3.956 V is attributed to the $\mathrm{LiMn}_{2} \mathrm{O}_{4} \leftrightarrow \mathrm{Li}_{0.5} \mathrm{Mn}_{2} \mathrm{O}_{4}$ reaction, whereas the second set at $4.178 / 4.077 \mathrm{~V}$ is related to the further insertion/extraction $\mathrm{Li}_{0.5} \mathrm{Mn}_{2} \mathrm{O}_{4} \leftrightarrow \mathrm{Li}_{\varepsilon} \mathrm{Mn}_{2} \mathrm{O}_{4}$ process (with $\mathrm{Li}_{\varepsilon} \mathrm{Mn}_{2} \mathrm{O}_{4}$ close to $\lambda-\mathrm{MnO}_{2}$ ). The same behavior was observed for the $\mathrm{Ag} / \mathrm{LMO}(\mathrm{v})$ electrode, which has the first redox peak at $4.050 / 3.930 \mathrm{~V}$ and the second redox peak at $4.180 / 4.067 \mathrm{~V}$. The measured peak current ratio $\left(i_{\mathrm{pa}} / i_{\mathrm{pc}}\right)$ for the two samples is close to 1 even at subsequent cycles; this is indicative of relative insertion and extraction reaction and transport rates of $\mathrm{Li}$ ions in both samples [86]. It is obvious that, for the $\mathrm{Ag} / \mathrm{LMO}$ prepared in vacuum, the anodic and cathodic peaks remain well-separated upon cycling with a slightly lower intensity of the anodic and cathodic peaks due to the better conductivity of the surface of particles with Ag coating. CV curves show that the coating realized under vacuum is beneficial for the cyclability and reversibility of the LMO electrode and does not affect the charge transfer at the electrode-electrolyte interface. The small potential difference in peak potential, $\Delta E_{\mathrm{P}}=0.1 \mathrm{~V}$, reflects the high rate capability of the $\mathrm{Ag} / \mathrm{LMO}(\mathrm{v})$ electrode. In contrast, the $\mathrm{CV}$ curves of $\mathrm{Ag} / \mathrm{LMO}$ prepared in air (Figure 10c) exhibit a broadening in the anodic and cathodic peaks with high polarization of $\Delta E_{\mathrm{P}}=0.338 \mathrm{~V}$ for the first redox peak and $\Delta E_{\mathrm{P}} 0.336 \mathrm{~V}$ for the second set. This broadening and large potential difference $\Delta E_{\mathrm{P}}$ for $\mathrm{Ag} / \mathrm{LMO}$ (a) is indicative of a poor reversibility and the presence of an insulating layer that hinders the charge transfer. This poor performance is attributed to the poor electronic conduction of $\mathrm{AgO}\left(\sigma_{\mathrm{e}} \sim 10^{-5} \mathrm{~S} \mathrm{~cm}^{-1}\right)$ [54].

The GCD profiles of the Li//LMO cells are presented in Figure 11. Experiments were carried out at $15 \mathrm{~mA} \mathrm{~g}^{-1}$ rate in the potential range 3.0-4.5 V over 60 cycles. All charge-discharge curves exhibit two voltage plateaus at ca. 4.0 (phase transition I) and ca. $4.15 \mathrm{~V}$ (phase transition II). They are typical of the well-crystallized $\mathrm{LiMn}_{2} \mathrm{O}_{4}$ spinel structure, which implies the existence of two steps for the extraction/insertion of $\mathrm{Li}$ ions from/into the LMO lattice [87-90]. Each step corresponds to the cathodic or anodic peaks observed in voltammograms and originate from the existence of a homogeneous 
$\mathrm{Li}_{1-\mathrm{x}} \mathrm{Mn}_{2} \mathrm{O}_{4}$ cubic phase $(0 \leq \mathrm{x} \leq 0.5)$ followed by a two-phase system implying the $\mathrm{Li}_{0.5} \mathrm{Mn}_{2} \mathrm{O}_{4}$ and $\mathrm{Li}_{\mathrm{x}} \mathrm{Mn}_{2} \mathrm{O}_{4}(\mathrm{x}<0.2)$ ended cubic phases during oxidation and reduction processes in the potential range 3.0-4.5 V. For the pristine $\mathrm{LMO}$ and $\mathrm{Ag} / \mathrm{LMO}(\mathrm{v})$ electrodes, the charge step voltages occur at 4.014 and $4.134 \mathrm{~V}$ and the discharge step voltages at 4.115 and $3.995 \mathrm{~V}$. In contrast, the charge-discharge curves of the $\mathrm{Li} / / \mathrm{Ag} / \mathrm{LMO}(\mathrm{a})$ cell exhibit less pronounced voltage plateaus. A slight sloping of charge-discharge curves appears upon cycling indicating the increase of the cell polarization caused by the presence of the highly resistive $\mathrm{AgO}$ phase on the surface of LMO particles.
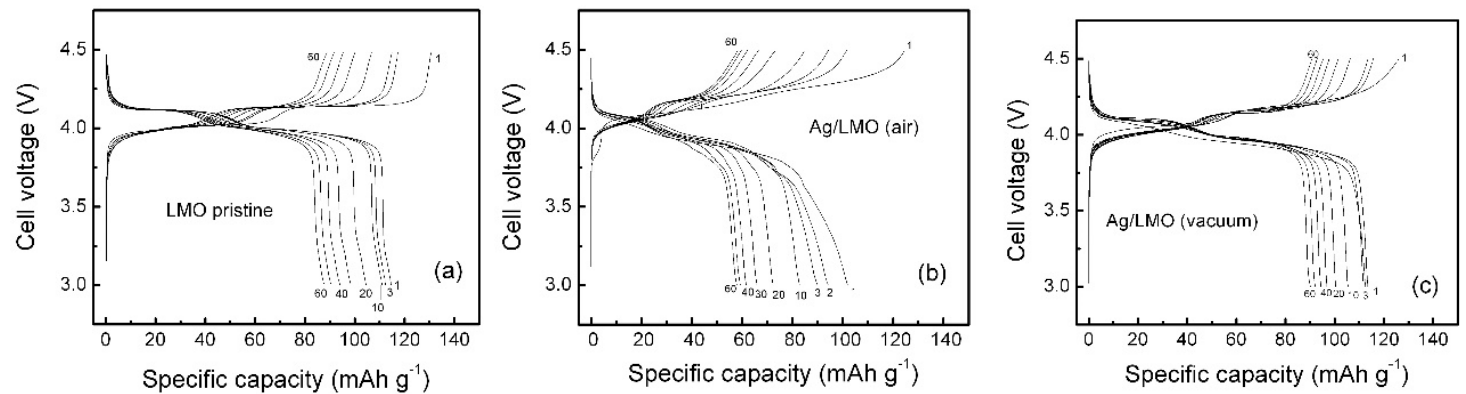

Figure 11. Galvanostatic charge-discharge profiles of Li//LMO cells. Experiments were carried out at $15 \mathrm{~mA} \mathrm{~g}^{-1}$ rate in the potential range 3.0-4.5 V over 60 cycles. Positive electrodes are: (a) pristine LMO; (b) $\mathrm{Ag} / \mathrm{LMO}(\mathrm{a})$; and (c) $\mathrm{Ag} / \mathrm{LMO}(\mathrm{v})$.

The initial specific discharge capacities delivered by pristine $\mathrm{LMO}, \mathrm{Ag} / \mathrm{LMO}(\mathrm{v})$ and $\mathrm{Ag} / \mathrm{LMO}(\mathrm{a})$ electrodes when cycled at $15 \mathrm{~mA} \mathrm{~g}^{-1}$ rate are 115,105 and $118 \mathrm{mAh} \mathrm{g}^{-1}$, respectively, with a capacity retention of $76 \%, 82 \%$ and $58 \%$ after 60 cycles. The $\mathrm{Ag} / \mathrm{LMO}$ (v) electrode shows the best electrochemical performance in terms of capacity retention and coulombic efficiency of $98.5 \%$ despite its low initial capacity compared with pristine LMO. Improvement of the electrochemical performance is attributed to the higher surface area and lower electrical resistance of the LMO surface produced by the deposition of silver nanospheres. These results show that $3 \mathrm{wt} . \% \mathrm{Ag}$ deposit is suitable; high silver content could form a barrier for the motion of $\mathrm{Li}^{+}$ions resulting in a large decrease of the rate capability [91].

The differential capacity curves $(-\mathrm{d} Q / \mathrm{d} V$ vs. $V)$ were plotted to analyze the lithiation/delithiation processes (i.e., study of redox potentials) in LMO electrodes. These plots differentiate the chargedischarge capacity $(Q)$ from data in galvanostatic charge-discharge curves with respect to the cell voltage and transform voltage plateaus on the $V-Q$ curves into peaks, which further characterize the electrochemical behavior of coated or doped electrodes and identify the gradual changes (if any) after the subsequent lithiation/delithiation process [92,93]. This method can be more accurate than cyclic voltammetry if measurements are carried out at low current density $\left(\leq 15 \mathrm{~mA} \mathrm{~g}^{-1}\right)$. In Figure 12, we demonstrate the $-\mathrm{d} Q / \mathrm{d} V$ vs. $V$ plots measured during the 2 nd and 60 th cycles from $3.0 \mathrm{~V}$ to the anodic cutoff potential of $4.5 \mathrm{~V}$ at $0.1 \mathrm{C}$ rate to verify the structural stability during cycling of the three LMO electrodes. The differential capacity profiles in galvanostatic conditions for all LMO electrodes show similar behavior. The difference in the shape of plateau I (at $\sim 4.0 \mathrm{~V}$ ) and plateau II (at $\sim 4.15 \mathrm{~V}$ ) are clearly seen in the $-\mathrm{d} Q / \mathrm{d} V$ vs. $V$ curves. Oxidation peak II is significantly broadened in the $\mathrm{Ag} / \mathrm{LMO}(\mathrm{a})$ and $\mathrm{Ag} / \mathrm{LMO}(\mathrm{v})$ electrodes, which is likely because of the existence of the $\mathrm{AgO}$ layer on the surface of the LMO particles. The phase transition process is influenced by this layer because of the modification of the crystal structure on the surface, which results in a potential shift of the redox reactions. Table 5 lists the oxidation (anodic) potentials $V_{\mathrm{ox}}{ }^{(\mathrm{I}, \mathrm{II})}$ of the phases I and II and the difference between oxidation and reduction potentials $\Delta V=V_{\text {ox }}-V_{\text {red }}$. These results evidence the increase of $\Delta V$ due to the polarization provoked by the silver oxide coating; furthermore, the presence of metallic $\mathrm{Ag}$ nanospheres in $\mathrm{Ag} / \mathrm{LMO}(\mathrm{v})$ compensates the presence of the non-conductive $\mathrm{AgO}$ layer, which, however, prevents side reactions and $\mathrm{Mn}$ dissolution for both $\mathrm{Ag} / \mathrm{LMO}(\mathrm{a})$ and $\mathrm{Ag} / \mathrm{LMO}(\mathrm{v})$ electrodes. 

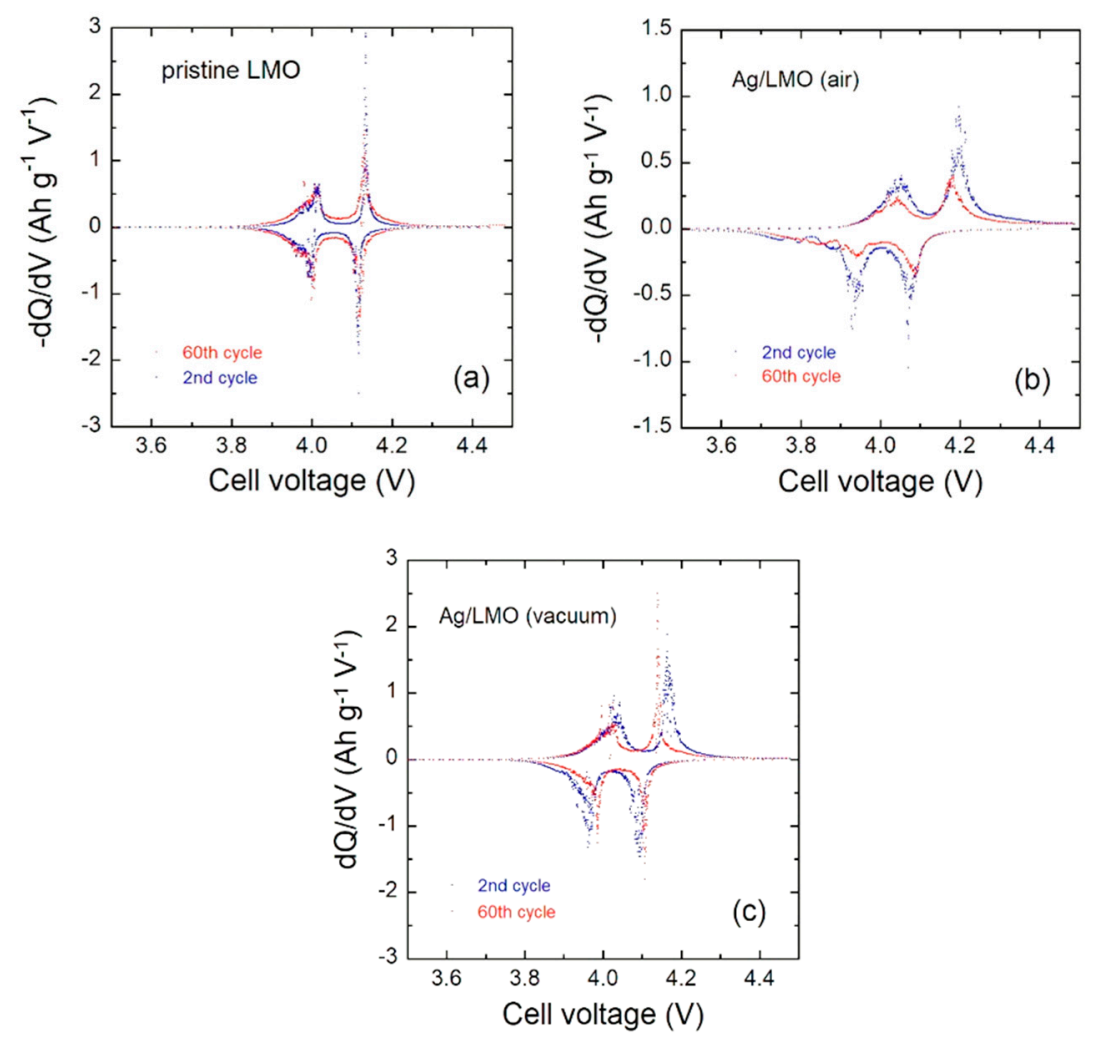

Figure 12. Incremental capacity $(-\mathrm{d} Q / \mathrm{d} V$ vs. $V)$ curves at the 2 nd and 60th cycles extracted from data of galvanostatic measurements carried out at $0.1 \mathrm{C}$ rate for: (a) pristine $\mathrm{LMO}$; (b) Ag/LMO(a); and (c) $\mathrm{Ag} / \mathrm{LMO}(\mathrm{v})$ electrodes.

Table 5. Results of the differential capacity analysis. The potential difference $\Delta V=V_{\mathrm{ox}}-V_{\text {red }}$ is given for the phases I and II.

\begin{tabular}{ccccc}
\hline Samples & $\begin{array}{c}\boldsymbol{V}_{\mathbf{o x}}^{(\mathbf{I})} \\
(\mathbf{V})\end{array}$ & $\begin{array}{c}\Delta \boldsymbol{V}^{(\mathbf{I})} \\
(\mathbf{m} \mathbf{V})\end{array}$ & $\begin{array}{c}\boldsymbol{V}_{\mathbf{o x}}^{(\mathbf{I I})} \\
\mathbf{( V )}\end{array}$ & $\begin{array}{c}\Delta \boldsymbol{V}^{(\mathbf{I I})} \\
(\mathbf{m V} \mathbf{V})\end{array}$ \\
\hline 2nd cycle & & & & \\
pristine LMO & 4.014 & 19 & 4.134 & 19 \\
Ag-LMO(a) & 4.05 & 123 & 4.198 & 126 \\
Ag-LMO(v) & 4.036 & 69 & 4.162 & 72 \\
\hline 60th cycle & & & & \\
pristine LMO & 4.005 & 13 & 4.132 & 13 \\
Ag-LMO(a) & 4.04 & 98 & 4.179 & 91 \\
Ag-LMO(v) & 4.023 & 32 & 4.14 & 35 \\
\hline
\end{tabular}

Figure 13a illustrates the cycling performance the LMO electrodes in the voltage range 3.0-4.5 V. The cyclability was investigated at $15 \mathrm{~mA} \mathrm{~g}^{-1}$ rate over 60 cycles. This figure shows that the Ag/LMO(v) sample exhibits better cyclability than the pristine $\mathrm{LMO}$ and $\mathrm{Ag} / \mathrm{LMO}(\mathrm{a})$ samples within 60 cycles. The capacity retention of the $\mathrm{Ag} / \mathrm{LMO}(\mathrm{v})$ electrode $(81.9 \%)$ is higher than that of pristine one $(76.6 \%)$ and displays a better coulombic efficiency of $99.4 \%$ compared to $98.1 \%$ for LMO cycled over 60 cycles. At $75 \mathrm{~mA} \mathrm{~g}^{-1}$ current density the capacity fade is only $0.06 \%$ per cycle (in 60 cycles) for the $\mathrm{Ag} / \mathrm{LMO}(\mathrm{v})$ electrode. The detrimental effect of the AgO layer deposited on $\mathrm{Ag} / \mathrm{LMO}$ treated in air is evidenced by the poor capacity retention of $58.2 \%$. Figure $13 \mathrm{~b}$ compares the electrochemical performance of the $\mathrm{Ag} / \mathrm{LMO}(\mathrm{v})$ electrode cycled at 15 and $75 \mathrm{~mA} \mathrm{~g}^{-1}$ rate. After 40 cycles, the specific discharge capacity of the $\mathrm{Ag} / \mathrm{LMO}(\mathrm{v})$ composite is higher at high rates, i.e., $75 \mathrm{~mA} \mathrm{~g}^{-1}$, compared with that at lower current density. It could be attributed to the effective reduction of the cathode-electrolyte interface polarization of the cell due to higher electronic conductivity of the composite electrode. 
Similar phenomena were found not only for $\mathrm{Ag} / \mathrm{LiMn}_{2} \mathrm{O}_{4}$ composites [45] but also in other Ag-based composites such as $\mathrm{Ag} / \mathrm{LiCoO}$ and $\mathrm{Ag}-\mathrm{Li}_{4} \mathrm{Ti}_{5} \mathrm{O}_{12}$. Huang et al. [94] reported that the discharge capacity of the Ag-doped $\mathrm{Li}_{4} \mathrm{Ti}_{5} \mathrm{O}_{12}$ was slightly lower than that of the undoped one at $30 \mathrm{~mA} \mathrm{~g}^{-1}$, while the discharge capacities of the composite electrode became much higher than those of the undoped one when the charge-discharge rate increased. The $\mathrm{Ag}-\mathrm{LiCoO}_{2} \mathrm{composite}$ electrode delivered a higher specific discharge capacity at $10 \mathrm{C}$ than that at $8 \mathrm{C}$ [38]. Figure 13c shows that the coulombic efficiency for the $\mathrm{Ag} / \mathrm{LMO}(\mathrm{v})$ electrode remains at $99 \%$ after 80 cycles at $15 \mathrm{~mA} \mathrm{~g}^{-1}$.
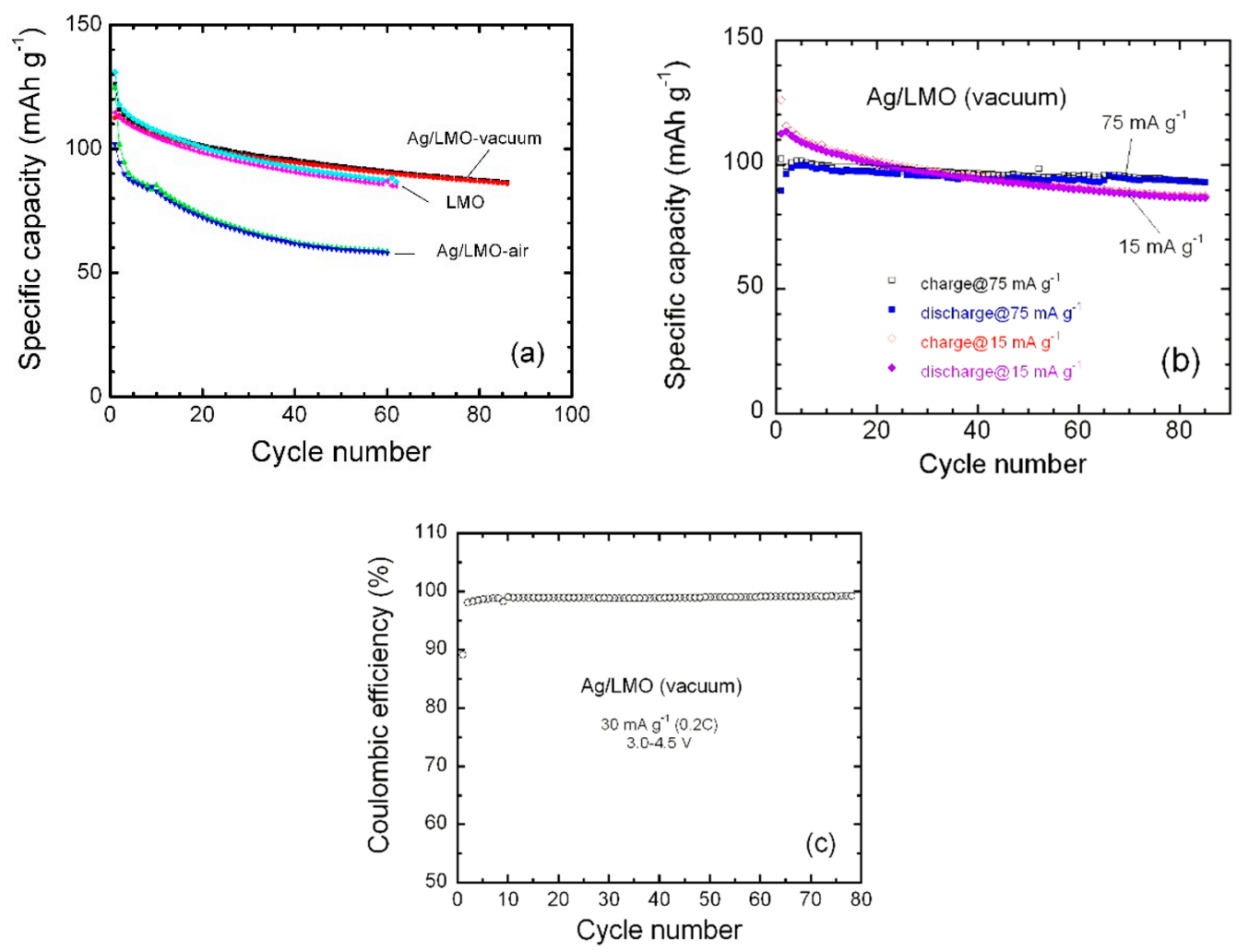

Figure 13. (a) Cyclability of pristine $\mathrm{LMO}, \mathrm{Ag} / \mathrm{LMO}(\mathrm{v})$ and $\mathrm{Ag} / \mathrm{LMO}(\mathrm{a})$ electrodes tested within the voltage range 3.0-4.5 $\mathrm{V}$ at $\mathrm{C} / 10$ rate; (b) cyclability of pristine $\mathrm{LMO} \mathrm{Ag} / \mathrm{LMO}(\mathrm{v})$ tested at $\mathrm{C} / 10$ and $\mathrm{C} / 2$ rate; and (c) Coulombic efficiency of the $\mathrm{Ag} / \mathrm{LMO}(\mathrm{v})$ electrode.

\subsection{Transport Properties}

To examine changes of the transport parameters of LMO electrodes, i.e., electrode-electrolyte interface resistance and $\mathrm{Li}^{+}$ion kinetics, EIS tests were carried out after five cycles at $15 \mathrm{~mA} \mathrm{~g}^{-1}$ to get insight into the origin of the difference in electrochemical performance of Ag-coated LMO. The Nyquist plots of pristine and Ag-coated $\mathrm{LiMn}_{2} \mathrm{O}_{4}$ electrodes are presented in Figure 14a. Experimentally, each EIS spectrum displays four regions, which can be modeled by the elements of the equivalent circuit (Figure 14b): (i) the intercept at high frequency with the $Z^{\prime}$-axis is related to the uncompensated ohmic resistance of the cell $\left(R_{\mathrm{S}}\right)$; (ii) in the high-frequency region, where the first depressed semicircle is associated with the solid electrolyte interphase (SEI) layer (resistance $R_{\text {SEI }}$ and constant-phase element $\mathrm{CPE}_{\mathrm{SEI}}$ ); (iii) the medium-frequency domain, where the second depressed semicircle is ascribed to the charge-transfer impedance $\left(R_{\mathrm{ct}}, \mathrm{CPE} \mathrm{dl}_{\mathrm{dl}}\right)$ at the electrode-electrolyte interface, in which the constant phase element is expressed by $\mathrm{CPE}=1 / T\left[(j \omega)^{\mathrm{p}}\right]$, with $\omega$ the angular frequency, $T$ the CPE constant, $p$ an exponent $(0 \leq p \leq 1, p=1$ for pure capacitance) and $j$ the imaginary number $(j=\sqrt{ }-1)$; and (iv) the low-frequency range, where the inclined line is ascribed to the $\mathrm{Li}^{+}$-ion diffusion-controlled process characterized by the Warburg impedance taken in the infinite limit and expressed by the relation $Z_{\mathrm{w}}(\omega)$ 
$=\sigma_{\mathrm{w}}(1-j) \omega^{-1 / 2}$, with $\sigma_{\mathrm{w}}$ the Warburg factor [95]. The real part of the impedance $Z^{\prime}(\omega)$ is the sum of the real part of the four components:

$$
\mathrm{Z}^{\prime}(\omega)=R_{\mathrm{S}}+R_{\mathrm{SEI}}+R_{\mathrm{ct}}+\sigma_{\mathrm{w}} \omega^{-1 / 2},
$$

Figure $14 \mathrm{c}$ presents the real part of $Z$ vs. $\omega^{-1 / 2}$ of the LMO electrodes in the low-frequency range to determine the Warburg factor (i.e., slope of the regression line). The apparent diffusion coefficient $D_{\mathrm{Li}}$ can be calculated according the following relation [96]:

$$
\sigma_{w}=\frac{R T}{n^{2} F^{2} A \sqrt{2}}\left(\frac{1}{C_{L i} \sqrt{D_{L i}}}\right)
$$

in which $R$ is the gas constant, $T$ is the absolute temperature, $F$ is the Faraday's constant, $n$ is the number of electrons transferred $(n=1), C_{L i}$ is the concentration of $\mathrm{Li}^{+}$-ion inside the LMO electrode and $A$ the effective surface area of the electrode. Results of the fits are listed in Table 6.
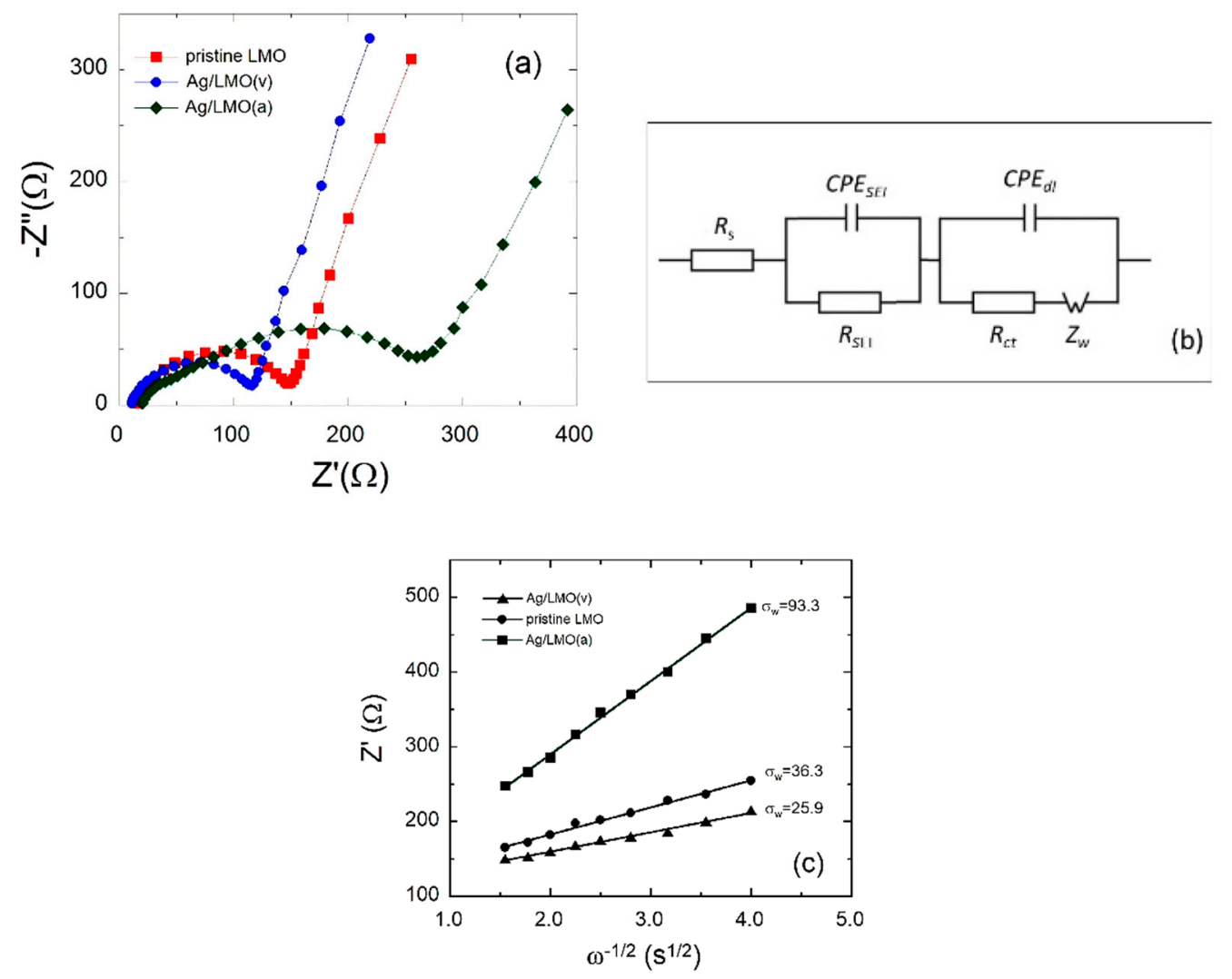

Figure 14. (a) Nyquist plots of as-prepared pristine LMO and Ag-coated LMO electrodes; (b) equivalent circuit model for EIS fitting; and (c) plots of the real part of the impedance vs. $\omega^{-1 / 2}$.

\begin{tabular}{|c|c|c|c|c|c|c|}
\hline \multirow{2}{*}{ Sample } & \multirow{2}{*}{$\begin{array}{l}R_{\mathrm{s}} \\
(\Omega)\end{array}$} & \multirow{2}{*}{$\begin{array}{l}R_{\mathrm{ct}} \\
(\Omega)\end{array}$} & \multicolumn{2}{|c|}{$\mathrm{CPE}_{\mathrm{dl}}$} & \multirow{2}{*}{$\begin{array}{c}\sigma_{w} \\
\left(\Omega s^{-1 / 2}\right)\end{array}$} & \multirow{2}{*}{$\begin{array}{c}D_{\mathrm{Li}} \\
\left(\mathrm{cm}^{2} \mathrm{~s}^{-1}\right)\end{array}$} \\
\hline & & & $T$ & $p$ & & \\
\hline pristine LMO & 17 & 133 & $3.6 \times 10^{-3}$ & 0.88 & 36.3 & $3.2 \times 10^{-12}$ \\
\hline $\mathrm{Ag} / \mathrm{LMO}(\mathrm{a})$ & 20 & 234 & $4.8 \times 10^{-3}$ & 0.94 & 25.9 & $4.8 \times 10^{-13}$ \\
\hline $\mathrm{Ag} / \mathrm{LMO}(\mathrm{v})$ & 11 & 100 & $1.1 \times 10^{-3}$ & 0.81 & 93.3 & $6.3 \times 10^{-12}$ \\
\hline
\end{tabular}

Table 6. Transport parameters of LMO electrodes deduced from EIS measurements. 
The $\mathrm{Ag} / \mathrm{LMO}(\mathrm{v})$ electrode exhibits a significant decrease of the $R_{c t}$ value, which is a direct indication of an increase of electrical transfer at the interface resulting in an increase of rate capability. The exchange current $I_{0}$ is calculated according to the relation:

$$
I_{0}=\frac{R T}{n F} \frac{1}{R_{c t}}
$$

The higher value of $I_{0}$ of $258 \mu \mathrm{A}$ for the $\mathrm{Ag} / \mathrm{LMO}(\mathrm{v})$ electrode (against 193 and $110 \mu \mathrm{A}$ for pristine $\mathrm{LMO}$ and $\mathrm{Ag} / \mathrm{LMO}(\mathrm{a})$, respectively) implies an easier electrochemical reaction on the surface. Moreover, the apparent diffusion coefficient of $\mathrm{Li}^{+}$ion in the $\mathrm{Ag} / \mathrm{LMO}(\mathrm{v})$, i.e., $6.3 \times 10^{-12} \mathrm{~cm}^{2} \mathrm{~s}^{-1}$ is twice $D_{\mathrm{Li}}$ in pristine LMO.

Another test for the electrochemical performance of a Li-insertion electrode is the evaluation of the area-specific impedance (ASI expressed in $\Omega \mathrm{cm}^{2}$ ) that evidences the change in the overall cell potential as a function of the depth of charge (DOD) given by the relation $[97,98]$ :

$$
A S I=A \frac{\left(O C V-V_{\text {cell }}\right)}{I},
$$

where $A$ is the cross-sectional area of the electrode, $\triangle V=O C V-V_{\text {cell }}$ is the potential change during current interruption for $60 \mathrm{~s}$ at each DOD and $I$ is the current passed throughout the cell. Figure 15 presents the variation of ASI for the LMO electrodes. ASI values are 32,26 and $58 \Omega \mathrm{cm}^{2}$ for the pristine $\mathrm{LMO}, \mathrm{Ag} / \mathrm{LMO}(\mathrm{v})$ and $\mathrm{Ag} / \mathrm{LMO}(\mathrm{a})$, respectively, at $90 \%$ DOD. The curves in Figure 15 indicate that, during battery charging, the charge-transfer resistance is dependent of DOD. These results match well with the work of Amine et al. [98], who reported an ASI of $25 \Omega \cdot \mathrm{cm}^{2}$ for a $\mathrm{LiMn}_{2} \mathrm{O}_{4}$ electrode subjected to a pulse of $18 \mathrm{~s}$.

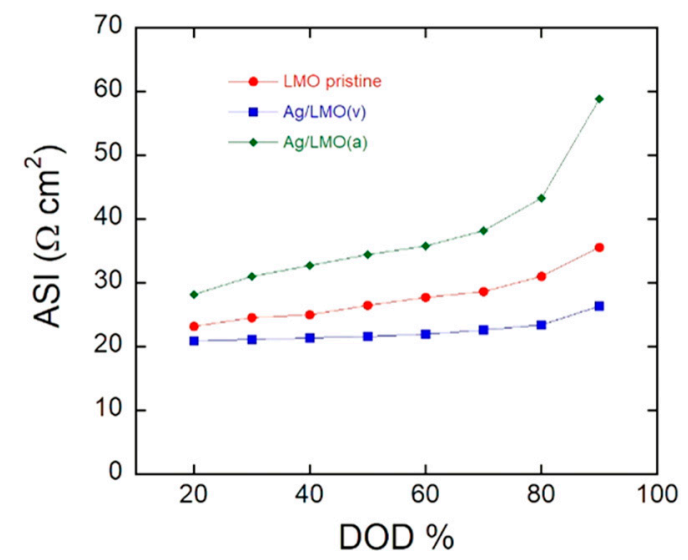

Figure 15. Area specific impedance (ASI) of parent $\mathrm{LMO}$ and $\mathrm{Ag}$-coated $\mathrm{LiMn}_{2} \mathrm{O}_{4}$ as a function of depth of discharge (DOD).

\section{Discussion}

Improvement of calendar and cycling life are issues requiring sophisticated technology to prevent degradation mechanisms of a lithium electrochemical cell. Surface modification of the electrode materials is part of the solution. It is generally accepted that coating layer improves the structural stability and decreases the disorder of cations in crystal sites, but at the expense of compromising the practical capacity and/or the energy density of electrode material $[99,100]$. During charge-discharge process of a LIB, the charge transfer in an insertion compound (either anode or cathode) implies the simultaneous local transport of both electrons and lithium ions. In an ideal electrode, electrons must directly reach positions where $\mathrm{Li}^{+}$ions take place. Generally, the electron-transfer pathway is ensured by carbonaceous additive (Ketjen black carbon, acetylene black, graphite powders, vapor-carbon fibers, etc.) [101,102], but, in some cases, for olivine cathode materials for example, a carbon coating 
is necessary to perform good contact-bridges between particles because the interparticle resistance. It makes the electrons and $\mathrm{Li}^{+}$ions locally inserted into the particles. Noble metals such as silver and gold have been also suggested [33,40-47]. We can expect better electrochemical performance at high rate with the employment of very small amount of these noble metals because the electrons arriving at the surface of particles are rapidly driven to the current collector. Since Ag or Au does not provide any electrochemical reaction, the presence of metallic nanoparticles in the deposit does not provoke any problem in the electrode performance.

Several techniques have been employed to deposit the conductive species on $\mathrm{LiMn}_{2} \mathrm{O}_{4}$ particles such as ion-sputtering deposition [33], co-deposition method in solution [103], electrodeposition [104], chemical deposition using aqueous or alcoholic solution [43,45,47-49]. In the present study, a new process was used including an alcoholic-type chemical deposition with complexing agent, which produced Ag nanospherical particles ( $20 \mathrm{~nm}$ in diameter) deposited on the LMO particles with an almost monodisperse distribution. This deposit is well attached to the LMO surface. Phase analysis showed that Ag did not enter the spinel structure. Combined results from Rietveld refinements, Raman and XPS spectroscopy indicated that LMO nanoparticles are covered by metallic Ag and $\mathrm{AgO}$ phases. To the best our knowledge, no study is devoted to the presence of silver oxide on the surface of Ag-modified cathodes although oxidation of silver is a native reaction depending on the atmosphere. The Ag nanospheres insure the interparticle electronic contact, which enhances the overall electrochemical performance, while the AgO thin layer suppresses the undesired side reactions between electrode and electrolyte, therefore slowing down the SEI formation on the LMO surface and suppression of the release of Mn ions in the electrolyte. Therefore, the Ag nanospheres have a positive effect not only on the electron kinetics but also on the lithium insertion/deinsertion process, by reducing the charge transfer resistance.

A comparison of the electrochemical performance of Ag-modified $\mathrm{LiMn}_{2} \mathrm{O}_{4}$ composite electrodes reported thus far in the literature is presented in Table 5. However, well-dispersed and few-nanometer sized Ag nanoparticles are obtained using ascorbic acid $\left(\mathrm{C}_{6} \mathrm{H}_{8} \mathrm{O}_{6}\right)$ and table sugar $\left(\mathrm{C}_{12} \mathrm{H}_{22} \mathrm{O}_{11}\right)$. Different concentrations of Ag have been tested and $\sim 3 \mathrm{wt} . \%$ seems to be the best one [43]. These $3 \mathrm{wt} . \%$ of Ag are enough to ensure a good contact bridging effect, further amount could form a barrier for the $\mathrm{Li}^{+}$ion transport. In contrast to the work of Huang et al. [45], the stability of our Ag-modified electrode calcined in vacuum is remarkable. The two sets of redox peaks shown in voltammograms are identical to those of pristine LMO and remain stable upon cycling. However, the better reversible capacity and cycling stability was also observed for electrode cycled at high C-rates. Note that data listed in Table 7 are also comparable with those reported for the $\mathrm{Au}-\mathrm{TiO}_{2}$-coated $\mathrm{LiMn}_{2} \mathrm{O}_{4}$ electrode prepared by co-deposition method, which delivered a specific capacity of $110 \mathrm{mAh} \mathrm{g}^{-1}$ after 100 cycles at $\mathrm{C} / 5$ rate [99].

Table 7. Comparison of the electrochemical performance of Ag-modified $\mathrm{LiMn}_{2} \mathrm{O}_{4}$ composite electrodes.

\begin{tabular}{ccccc}
\hline $\begin{array}{c}\text { Reducing } \\
\text { Agent }\end{array}$ & $\begin{array}{c}\text { Ag Content } \\
\text { (wt. } \%)\end{array}$ & $\begin{array}{c}\text { Ag Particle } \\
\text { Size } \\
\text { (nm) }\end{array}$ & Electrochemical Performance & Ref. \\
\hline $\mathrm{NH}_{4} \mathrm{OH}$ & 3.2 & $10-100$ & $91 \mathrm{mAh} \mathrm{g}^{-1} @ 2 \mathrm{C}-20$ cycles & {$[43]$} \\
$\mathrm{NH}_{4} \mathrm{OH}$ & 6.3 & $10-50$ & $109 \mathrm{mAh} \mathrm{g}^{-1} @ 200 \mathrm{~mA} \mathrm{~g}^{-1}-50$ cycles & {$[45]$} \\
$\mathrm{C}_{12} \mathrm{H}_{22} \mathrm{O}_{11}$ & 5 & $3-5$ & $110 \mathrm{mAh} \mathrm{g}^{-1} @ \mathrm{C} / 2-50$ cycles & {$[48]$} \\
$\mathrm{HNO}_{3}$ & 8 & $100-200$ & $42 \mu \mathrm{Ah} \mathrm{cm}^{-2} \mu \mathrm{m}^{-1} @ 100 \mu \mathrm{A} \mathrm{cm}-50$ cycles & {$[46]$} \\
- & 6 & spot & $108 \mathrm{mAh} \mathrm{g}^{-1} @ \mathrm{C} / 3-40$ cycles & {$[47]$} \\
$\mathrm{C}_{6} \mathrm{H}_{8} \mathrm{O}_{6}$ & 3 & $\sim 20$ & $95 \mathrm{mAh} \mathrm{g}^{-1} @ 75 \mathrm{~mA} \mathrm{~g}-80$ cycles & this work \\
\hline
\end{tabular}

The present study also shows that the porous architecture of $\mathrm{Ag} / \mathrm{LMO}$ composites has several advantages: (i) It can help to alleviate the structure changes caused by the lithium insertion/extraction, which significantly improves the cyclability of the cathode materials. (ii) The porous three-dimensional nanoparticles provide more active surface area for electrochemical reactions. (iii) The optimal pore 
diameter is better for energy storage as it favors the ion transport (increase of exchange current). This indicates a faster $\mathrm{Li}$ ion transport in bigger pores; $D_{\mathrm{Li}}$ of $\mathrm{Ag} / \mathrm{LMO}(\mathrm{v})$ is twice that pristine $\mathrm{LMO}$, which likely contributes to the higher rate capability.

\section{Conclusions}

In this study, $\mathrm{LiMn}_{2} \mathrm{O}_{4}$ spinel cathode material has been coated with silver using a facile, scalable and wet-chemical method. The Ag coating deposited on the LMO particles ( 400 nm in size) was obtained via heat treatment under ambient atmosphere (air) or in vacuum. The structure and morphology studies by Rietveld refinements, XPS and Raman spectroscopy show that calcination in air involves the formation of an insulating AgO thick layer, while treatment in vacuum maintains major AgNPs with in its metallic state in the form of nanospheres with minor AgO amount encapsulate LMO particles. The improved electrochemical performance of the Ag/LMO composite electrode heat-treated in vacuum is due to: (i) the enhanced specific surface area $\left(4.1 \mathrm{~m}^{2} \mathrm{~g}^{-1}\right)$; (ii) the increase of the mesoporosity, which could lead easy diffusion pathways for $\mathrm{Li}^{+}$ions to $\mathrm{LMO}$ particles; and (iii) the presence of the superficial conductive layer increasing the LMO interparticle electrical contact and the thin insulating $\mathrm{AgO}$ layer which prevents side reactions. In contrast, the presence of the relatively thick $\mathrm{AgO}$ insulating phase on the surface of $\mathrm{Ag} / \mathrm{LMO}$ particles treated in air acts as a barrier for the $\mathrm{Li}^{+}$ions motion. The $\mathrm{Ag} / \mathrm{LMO}(\mathrm{v})$ electrode shows high capacity retention, reduced side reaction effect, good cyclability and capacity fade of $0.06 \%$ per cycle (in 60 cycles).

Author Contributions: Conceptualization, A.M.H.; investigation, S.M.A., A.E.A.-G., E.H.I. and M.K.; writingoriginal draft preparation, A.M.H., S.M.A. and A.E.A.-G.; writing-review and editing, C.M.J.; and supervision, M.W. and J.L. All authors have read and agreed to the published version of the manuscript.

Funding: This research received no external funding.

Acknowledgments: A.M Hashem is grateful for the financial support from Science and Technology Development Fund (STDF) through the project number 23159 (Economical synthesis methods for nanosized energy storage cathode materials to be used in lithium-ion batteries). The authors are grateful to Matej Mičušík (Polymer Institute, Slovak Academy of Sciences, Bratislava, Slovak Republic) for his help in carrying out XPS measurements.

Conflicts of Interest: The authors declare no conflict of interest.

\section{References}

1. Julien, C.M.; Mauger, A.; Vijh, A.; Zaghib, K. Lithium Batteries: Science and Technology; Springer: Cham, Switzerland, 2016.

2. Arai, J.; Yamaki, T.; Yamauchi, S.; Yuasa, T.; Maeshima, T.; Sakai, T.; Koseki, M.; Horiba, T. Development of a high power lithium secondary battery for hybrid electric vehicles. J. Power Sources 2005, 146, 788-792. [CrossRef]

3. Park, O.K.; Cho, Y.; Lee, S.; Yoo, H.-C.; Song, H.-K.; Cho, J. Who will drive electric vehicles, olivine or spinel? Energy Environ. Sci. 2011, 4, 1621-1633. [CrossRef]

4. Zhang, J.; Lin, S.; Li, K.; Shua, F.; Chen, K.; Wang, L.; Xue, D. Synthesis of spinel $\mathrm{LiMn}_{2} \mathrm{O}_{4}$ cathode material by a modified solid state reaction. Funct. Mater. Lett. 2015, 8, 1540002. [CrossRef]

5. Xie, X.; Su, D.; Sun, B.; Zhang, J.; Wang, C.; Wang, G. Synthesis of single-crystalline spinel $\mathrm{LiMn}_{2} \mathrm{O}_{4}$ nanorods for lithium-ion batteries with high rate capability and long cycle life chemistry. Chem. Eur. J. 2014, 20, 17125-17131. [CrossRef] [PubMed]

6. Thackeray, M.M.; Yang, S.-H.; Kahaian, A.J.; Kepler, K.D.; Skinner, E.; Vaughey, J.T.; Hackney, S.A. Structural fatigue in spinel electrodes in high voltage (4 V) Li/Li $\mathrm{Mn}_{2} \mathrm{O}_{4}$ cells. Electrochem. Solid-State Lett. 1998, 1, 7-9. [CrossRef]

7. Naghash, A.R.; Lee, J.Y. Preparation of spinel lithium manganese oxide by aqueous co-precipitation. J. Power Sources 2000, 85, 284-293. [CrossRef]

8. Chan, H.W.; Duh, J.G.; Sheen, S.R. $\mathrm{LiMn}_{2} \mathrm{O}_{4}$ cathode doped with excess lithium and synthesized by co-precipitation for Li-ion batteries. J. Power Sources 2003, 115, 110-118. [CrossRef]

9. He, X.; Li, J.; Cai, Y.; Jiang, C.; Wan, C. Preparation of spherical spinel $\mathrm{LiMn}_{2} \mathrm{O}_{4}$ cathode material for Li-ion batteries. Mater. Chem. Phys. 2006, 95, 105-108. [CrossRef] 
10. Lee, K.S.; Myung, S.T.; Jung, H.G.; Lee, J.K.; Sun, Y.-K. Spinel lithium manganese oxide synthesized under a pressurized oxygen atmosphere. Electrochim. Acta 2010, 55, 8397-8401. [CrossRef]

11. Hashem, A.M.; Abbas, S.M.; Hou, X.; Eid, A.E.; Abdel-Ghany, A.E. Facile one step synthesis method of spinel $\mathrm{LiMn}_{2} \mathrm{O}_{4}$ cathode material for lithium batteries. Heliyon 2019, 5, e02027. [CrossRef]

12. Tian, L.; Yuan, A. Electrochemical performance of nanostructured spinel $\mathrm{LiMn}_{2} \mathrm{O}_{4}$ in different aqueous electrolytes. J. Power Sources 2009, 192, 693-697. [CrossRef]

13. Wei, C.; Deng, J.; Xi, L.; Zhou, H.; Wang, Z.; Chung, C.Y.; Yao, Q.; Rao, G. High power $\mathrm{LiMn}_{2} \mathrm{O}_{4}$ hollow microsphere cathode materials for lithium ion batteries. Int. J. Electrochem. Sci. 2013, 8, 6775-6783.

14. Xi, L.J.; Wang, H.-E.; Lu, Z.G.; Yang, S.L.; Ma, R.G.; Deng, J.Q.; Chung, C.Y. Facile synthesis of porous $\mathrm{LiMn}_{2} \mathrm{O}_{4}$ spheres as positive electrode for high-power lithium ion batteries. J. Power Sources 2012, 198, 251-257. [CrossRef]

15. Ding, Y.-L.; Zhao, X.-B.; Xie, J.; Cao, G.-S.; Zhu, T.-J.; Yu, H.-M.; Sun, C.-Y. Double-shelled hollow microspheres of $\mathrm{LiMn}_{2} \mathrm{O}_{4}$ for high-performance lithium ion batteries. J. Mater. Chem. 2011, 21, 9475-9479. [CrossRef]

16. Wu, Y.; Wen, Z.; Feng, H.; Li, J. Hollow porous $\mathrm{LiMn}_{2} \mathrm{O}_{4}$ microcubes as rechargeable lithium battery cathode with high electrochemical performance. Small 2012, 8, 858-862. [CrossRef]

17. Hirose, S.; Kodera, T.; Ogihara, T. Synthesis and electrochemical properties of Li-rich spinel type $\mathrm{LiMn}_{2} \mathrm{O}_{4}$ powders by spray pyrolysis using aqueous solution of manganese carbonate. J. Alloys Compd. 2010, 506, 883-887. [CrossRef]

18. Julien, C.; Ziolkiewicz, S.; Lemal, M.; Massot, M. Synthesis, structure and electrochemistry of $\mathrm{LiMn}_{2-\mathrm{y}} \mathrm{Al}_{\mathrm{y}} \mathrm{O}_{4}$ prepared by wet chemistry. J. Mater. Chem. 2001,11, 1837-1842. [CrossRef]

19. Töpfer, J.; Feltz, A. Investigations on electronically conducting oxide systems XXV. Electrical and crystallographic studies of the system $\mathrm{Li}_{\mathrm{z}} \mathrm{Cu}_{1-\mathrm{z}} \mathrm{Mn}_{2} \mathrm{O}_{4}$. J. Alloys Compd. 1993, 202, 231-235. [CrossRef]

20. Lee, H.R.; Seo, H.R.; Lee, B.; Cho, B.W.; Lee, K.-Y.; Oh, S.H. Spinel-structured surface layers for facile Li ion transport and improved chemical stability of lithium manganese oxide spinel. Appl. Surface Sci. 2017, 392, 448-455. [CrossRef]

21. Tong, Q.S.; Yang, Y.; Shi, J.C.; Yan, J.M.; Zhang, L.Q. Synthesis and storage performance of the doped $\mathrm{LiMn}_{2} \mathrm{O}_{4}$ spinel. J. Electrochem. Soc. 2007, 154, A656-A667. [CrossRef]

22. Liu, Q.; Wang, S.; Tan, H.; Yang, Z.; Zeng, J. Preparation and doping mode of doped $\mathrm{LiMn}_{2} \mathrm{O}_{4}$ for $\mathrm{Li}$-ion batteries. Energies (Basel) 2013, 6, 1718-1730. [CrossRef]

23. Xiong, L.; Xua, Y.; Taoa, T.; Goodenough, J.B. Synthesis and electrochemical characterization of multi-cations doped spinel $\mathrm{LiMn}_{2} \mathrm{O}_{4}$ used for lithium ion batteries. J. Power Sources 2012, 199, 214-219. [CrossRef]

24. Lee, Y.-S.; Kumada, N.; Yoshio, M. Synthesis and characterization of lithium aluminum-doped spinel $\left(\mathrm{LiAl}_{\mathrm{x}} \mathrm{Mn}_{2-\mathrm{x}} \mathrm{O}_{4}\right)$ for lithium secondary battery. J. Power Sources 2001, 96, 376-384. [CrossRef]

25. Julien, C.; Ruth-Mangani, I.R.; Selladurai, S.; Massot, M. Synthesis, structure and electrochemistry of $\mathrm{LiMn}_{2-\mathrm{y}} \mathrm{Cr}_{\mathrm{y} / 2} \mathrm{Cu}_{\mathrm{y} / 2} \mathrm{O}_{4}(0.0 \leq \mathrm{y} \leq 0.5)$ prepared by wet chemistry. Solid State Science 2002, 4, 1031-1038. [CrossRef]

26. Park, S.-C.; Kim, Y.-M.; Kang, Y.-M.; Kim, K.-T.; Lee, P.S.; Lee, J.-Y. Improvement of the rate capability of $\mathrm{LiMn}_{2} \mathrm{O}_{4}$ by surface coating with $\mathrm{LiCoO}_{2}$. J. Power Sources 2001, 103, 86-92. [CrossRef]

27. Zhang, Z.; Chou, S.; Gu, Q.; Liu, H.K.; Li, H. Enhancing the high rate capability and cycling stability of $\mathrm{LiMn}_{2} \mathrm{O}_{4}$ by coating of solid-state electrolyte $\mathrm{LiNbO}_{3}$. ACS Appl. Mater. Interfaces 2014, 6, 22155-22165. [CrossRef]

28. Sahan, H.; Göktepe, H.; Kilic-Dokan, F.; Aydin, A.; Veziroglu, S.; Patat, S. Improvement of cycling stability of $\mathrm{LiMn}_{2} \mathrm{O}_{4}$ cathode by $\mathrm{Al}_{2} \mathrm{O}_{3}$ surface coating for Li-ion batteries. Acta Phys. Polonica A 2013, 123, 368-370. [CrossRef]

29. Tron, A.; Park, Y.D.; Mun, J. $\mathrm{AlF}_{3}$-coated $\mathrm{LiMn}_{2} \mathrm{O}_{4}$ as cathode material for aqueous rechargeable lithium battery with improved cycling stability. J. Power Sources 2016, 325, 360-364. [CrossRef]

30. Lesel, B.K.; Ko, J.S.; Dunn, B.; Tolbert, S.H. Mesoporous $\mathrm{Li}_{x} \mathrm{Mn}_{2} \mathrm{O}_{4}$ thin film cathodes for lithium-ion pseudocapacitors. ACS Nano 2016, 10, 7572-7581. [CrossRef]

31. Luo, J.; Wang, Y.; Xiong, H.; Xia, Y. Ordered mesoporous spinel $\mathrm{LiMn}_{2} \mathrm{O}_{4}$ by a soft-chemical process as a cathode material for lithium-ion batteries. Chem. Mater. 2007, 19, 4791-4795. [CrossRef]

32. Xia, H.; Ragavendran, K.R.; Xie, J.; Lu, L. Ultrafine $\mathrm{LiMn}_{2} \mathrm{O}_{4} /$ carbon nanotube nanocomposite with excellent rate capability and cycling stability for lithium-ion batteries. J. Power Sources 2012, 212, 28-34. [CrossRef] 
33. Tu, J.; Zhao, B.; Cao, G.S.; Tu, J.P.; Zhu, T.J. Improved performance of $\mathrm{LiMn}_{2} \mathrm{O}_{4}$ cathode materials for lithium ion batteries by gold coating. Mater. Lett. 2006, 60, 3251-3254. [CrossRef]

34. Guan, J.; Liu, M. Transport properties of $\mathrm{LiMn}_{2} \mathrm{O}_{4}$ electrode materials for lithium-ion batteries. Solid State Ionics 1998, 110, 21-28. [CrossRef]

35. Pistoia, G.; Zane, D.; Zhang, Y. Some aspects of $\mathrm{LiMn}_{2} \mathrm{O}_{4}$ electrochemistry in the 4 volt range. J. Electrochem. Soc. 1995, 142, 2551-2557. [CrossRef]

36. Evanoff, D.D.; Chumanov, G. Synthesis and optical properties of silver nanoparticles and arrays. ChemPhysChem 2005, 6, 1221-1231. [CrossRef]

37. Obrovac, M.; Chevrier, V. Alloy negative electrodes for Li-ion batteries. Chem. Rev. 2014, 114, 11444-11502. [CrossRef]

38. Huang, S.H.; Wen, Z.Y.; Yang, X.L.; Gu, Z.H.; Xu, X.H. Improvement of the high-rate discharge properties of $\mathrm{LiCoO}_{2}$ with the Ag additives. J. Power Sources 2005, 148, 72-77. [CrossRef]

39. Peng, H.; Wu, W.; Zhang, C.; Li, G.; Chen, K. Synthesis and electrochemical properties of $\mathrm{Ag}_{0.33} \mathrm{~V}_{2} \mathrm{O}_{5}-\mathrm{V}_{2} \mathrm{O}_{5}$ core-shell nanobelts for rechargeable lithium batteries. Mater. Lett. 2011, 65, 3436-3439. [CrossRef]

40. Lu, Z.G.; Cheng, H.; Lo, M.F.; Chung, C.Y. Pulsed laser deposition and electrochemical characterization of $\mathrm{LiFePO}_{4}-\mathrm{Ag}$ composite thin films. Adv. Funct. Mater. 2007, 17, 3885-3896. [CrossRef]

41. Abuzeid, H.M.; Hashem, A.M.; Narayanan, N.; Ehrenberg, H.; Julien, C.M. Nanosized silver-coated and doped manganese dioxide for rechargeable lithium batteries. Solid State Ionics 2011, 182, 108-115. [CrossRef]

42. Huang, S.; Wen, Z.; Zhang, J.; Yang, X. Improving the electrochemical performance of $\mathrm{Li}_{4} \mathrm{Ti}_{5} \mathrm{O}_{12} / \mathrm{Ag}$ composite by an electroless deposition method. Electrochim. Acta 2007, 52, 3704-3708. [CrossRef]

43. Son, J.T.; Kim, H.G.; Park, Y.J. New preparation method and electrochemical property of $\mathrm{LiMn}_{2} \mathrm{O}_{4}$ electrode. Electrochim. Acta 2004, 50, 453-459. [CrossRef]

44. Son, J.; Park, K.; Kim, H.G.; Chung, H. Surface-modification of $\mathrm{LiMn}_{2} \mathrm{O}_{4}$ with a silver-metal coating. J. Power Sources 2004, 126, 182-185. [CrossRef]

45. Huang, S.; Wen, Z.; Yang, X.; Zhu, X.; Lin, B. Synthesis and the improved high-rate performance of $\mathrm{LiMn}_{2} \mathrm{O}_{4} / \mathrm{Ag}$ composite cathode for lithium-ion batteries. Electrochem. Solid State Lett. 2006, 9, A443-A447. [CrossRef]

46. Wu, X.M.; Chen, S.; He, Z.Q.; Ma, M.Y.; Xiao, Z.B.; Liu, J.B. Solution-derived lithium manganese oxide thin films with silver additive and their characterization. Mater. Chem. Phys. 2007, 101, 217-220. [CrossRef]

47. Zhou, W.-J.; He, B.-L.; Li, H.-L. Synthesis, structure and electrochemistry of Ag-modified $\mathrm{LiMn}_{2} \mathrm{O}_{4}$ cathode materials for lithium-ion batteries. Mater. Res. Bull. 2008, 43, 2285-2294. [CrossRef]

48. Jiang, R.; Cui, C.; Ma, H.; Ma, H.; Chen, T. Study on the enhanced electrochemical performance of $\mathrm{LiMn}_{2} \mathrm{O}_{4}$ cathode material at $55^{\circ} \mathrm{C}$ by the nano Ag-coating. J. Electroanal. Chem. 2015, 744, 69-76. [CrossRef]

49. Tay, S.F.; Johan, M.R. Synthesis, structure, and electrochemistry of Ag-modified $\mathrm{LiMn}_{2} \mathrm{O}_{4}$ cathode materials for lithium-ion batteries. Ionics 2010, 16, 859-863. [CrossRef]

50. Hou, Y.; Zhao, S.; Wu, Y.; van Ree, T. Spinel, $\mathrm{LiMn}_{2} \mathrm{O}_{4}$-based positive electrode materials. In Lithium-ion Batteries: Fundamentals and Applications; Wu, Y., Ed.; CRC Press: Boca Raton, FL, USA, 2015; pp. 59-94.

51. Moore, W.; Codella, P.J. Oxidation of silver films by atomic oxygen. J. Phys. Chem. 1988, 92, 4421-4426. [CrossRef]

52. Graff, W.S.; Stadelmaier, H.H. Higher oxides of silver. J. Electrochem. Soc. 1958, 105, 446-449. [CrossRef]

53. Liu, H.T.; Xia, X.; Guo, Z.P. A novel silver oxide electrode and its charge-discharge performance. J. Appl. Electrochem. 2002, 32, 275-279. [CrossRef]

54. Raju, N.R.C.; Kumar, K.J.; Subrahmanyam, A. Physical properties of silver oxide thin films by pulsed laser deposition: Effect of oxygen pressure during growth. J. Phys. D: Appl. Phys. 2009, 42, 135411. [CrossRef]

55. Rodriguez-Carjaval, J. Recent developments of the program FULLPROF. In Commission on Powder Diffraction (IUCr). Newsletter 2001, 26, 12-19.

56. Wu, H.; Tu, J.; Yuan, Y.; Chen, X.; Xiang, J.; Zhao, X.; Cao, G. One-step synthesis $\mathrm{LiMn}_{2} \mathrm{O}_{4}$ cathode by a hydrothermal method. J. Power Sources 2006, 161, 1260-1263. [CrossRef]

57. Thackeray, M.M. Manganese oxides for lithium batteries. Progr. Solid State Chem. 1997, 25, 1-71. [CrossRef]

58. Yu, Z.-M.; Zhao, L.-C. Structure and electrochemical properties of $\mathrm{LiMn}_{2} \mathrm{O}_{4}$. Trans. Nonferrous Metals Soc. Chin. 2007, 17, 659-664. [CrossRef]

59. Bao, S.-J.; Li, C.-M.; Li, H.-L.; Luong, J.H. Morphology and electrochemistry of $\mathrm{LiMn}_{2} \mathrm{O}_{4}$ optimized by using different Mn-sources. J. Power Sources 2007, 164, 885-889. [CrossRef] 
60. Williamson, G.K.; Hall, W.H. X-ray line broadening from filed aluminium and wolfram. Acta Metall. 1953, 1 , 22-31. [CrossRef]

61. Ramana, C.V.; Massot, M. Julien, C.M. XPS and Raman spectroscopic characterization of $\mathrm{LiMn}_{2} \mathrm{O}_{4}$ spinels. Surf. Interface Anal. 2005, 37, 412-416. [CrossRef]

62. Shin, D.W.; Choi, J.W.; Choi, W.K.; Cho, Y.S.; Yoon, S.J. XPS/EXAFS study of cycleability improved $\mathrm{LiMn}_{2} \mathrm{O}_{4}$ thin films cathodes prepared by solution deposition. Electrochem. Commun. 2009, 11, 695-698. [CrossRef]

63. Moulder, J.F.; Stickle, W.F.; Sobol, P.E.; Bomben, K.D. Handbook of X-ray photoelectron spectroscopy, Perkin-Elmer Corporation; Physical Electronics Division: Eden Prairie, MN, USA, 1992.

64. Kaspar, T.C.; Droubay, T.; Chambers, S.A.; Bagus, P.S. Spectroscopic evidence for Ag(III) in highly oxidized silver films by X-ray photoelectron spectroscopy. J. Phys. Chem. C 2010, 114, 21562-21571. [CrossRef]

65. XPS Data Base. Available online: http://www.xpsfitting.com/2013/04/silver.html (accessed on 1 January 2009).

66. Lopez-Salido, I.; Lim, D.C.; Kim, Y.D. Ag nanoparticles on highly ordered pyrolytic graphire (HOPG) surfaces studied using STM and XPS. Surf. Sci. 2005, 588, 6-18. [CrossRef]

67. Jimenez, J.A.; Liu, H.; Fachini, E. X-ray photoelectron spectroscopy of silver nanoparticles in phosphate glass. Mater. Lett. 2010, 64, 2046-2048. [CrossRef]

68. Tanaka, A.; Takeda, Y.; Imamura, M.; Sato, S. Dynamic final-state on the Au 4 f core-level photoemission of dodecanethiolate-passivated AU nanoparticles on graphite substrates. Phys. Rev. B 2003, 68, 195415. [CrossRef]

69. Granbohm, H.; Larismaa, J.; Ali, S.; Johansson, L.-S.; Hannula, S.-P. Control of the size of silver nanoparticles and release of silver in heat treated $\mathrm{SiO}_{2}$-Ag composite powders. Materials (Basel) 2018, 11, 80. [CrossRef] [PubMed]

70. Poyraz, A.S.; Kuo, C.-H.; Biswas, S.; King'ondu, C.K.; Suib, S.L. A general approach to crystalline and monomodal pore size mesoporous materials. Nat. Commun. 2013, 4, 2952. [CrossRef]

71. Jiao, F.; Bao, J.; Hill, A.H.; Bruce, P.G. Synthesis of ordered mesoporous Li-Mn-O spinel as a positive electrode for rechargeable lithium batteries. Angew. Chem. Int. Ed. 2008, 47, 9711-9716. [CrossRef]

72. Ammundsen, B.; Rozière, J.; Islam, M.S. Atomistic simulation studies of lithium and proton insertion in spinel lithium manganates. J. Phys. Chem. B 1997, 101, 8156-8163. [CrossRef]

73. Julien, C.; Rougier, A.; Haro-Poniatowski, E.; Nazri, G.A. Vibrational spectroscopy of lithium manganese spinel oxides. Mol. Cryst. Liq. Cryst. 1998, 311, 81-87. [CrossRef]

74. Julien, C.M.; Massot, M. Lattice vibrations of materials for lithium rechargeable batteries I. Lithium manganese oxide spinel. Mater. Sci. Eng. B 2003, 97, 217-230. [CrossRef]

75. Tsendzughul, N.T.; Ogwu, A.A. Physico Physicochemical aspects of the mechanisms of rapid antimicrobial contact-killing by sputtered silver oxide thin films under visible light. ACS Omega 2019, 4, 16847-16859. [CrossRef] [PubMed]

76. Waterhouse, G.I.N.; Bowmaker, G.A.; Metson, J.B. The thermal decomposition of silver (I, III) oxide: A combined XRD, FT-IR and Raman spectroscopic study. Phys. Chem. Chem. Phys. 2001, 3, 3838-3845. [CrossRef]

77. Wang, C.B.; Deo, G.; Wachs, I.E. Interaction of polycrystalline silver with oxygen, water, carbon dioxide, ethylene, and methanol: In situ Raman and catalytic studies. J. Phys. Chem. B 1999, 103, 5645-5656. [CrossRef]

78. Meng, E.; Zhang, M.; Hu, Y.; Gong, F.; Zhang, L.; Li, F. Solid-state attachments of Ag nanoparticles onto the surfaces of $\mathrm{LiFePO}_{4}$ cathode materials for Li storage with enhanced capabilities. Electrochim. Acta 2018, 265, 160-165. [CrossRef]

79. Albiter, E.; Valenzuala, M.; Alfaro, S.; Valverde-Aguilar, G.; Martinez, F. Photocatalytic deposition of Ag nanoparticles on $\mathrm{TiO}_{2}$ : Metal precursor effect on the structural and photoactivity properties. J. Saudi Chem. Soc. 2015, 19, 563-573. [CrossRef]

80. Tarascon, J.; McKinnon, W.; Coowar, F.; Bowmer, T.; Amatucci, G.; Guyomard, D. Synthesis conditions and oxygen stoichiometry effects on $\mathrm{Li}$ insertion into the spinel $\mathrm{LiMn}_{2} \mathrm{O}_{4}$. J. Electrochem. Soc. 1994, 141, 1421-1431. [CrossRef]

81. Bang, H.J.; Donepudi, V.; Prakash, J. Preparation and characterization of partially substituted $\mathrm{LiM}_{\mathrm{y}} \mathrm{Mn}_{2-\mathrm{y}} \mathrm{O}_{4}$ $(\mathrm{M}=\mathrm{Ni}, \mathrm{Co}, \mathrm{Fe})$ spinel cathodes for Li-ion batteries. Electrochim. Acta 2002, 48, 443-451. [CrossRef]

82. Liu, W.; Farrington, G.; Chaput, F.; Dunn, B. Synthesis and Electrochemical Studies of Spinel Phase $\mathrm{LiMn}_{2} \mathrm{O}_{4}$ Cathode Materials Prepared by the Pechini processes. J. Electrochem. Soc. 1996, 143, 879-884. [CrossRef] 
83. Santander, N.; Das, S.; Majumder, S.; Katiyar, R. Process optimization and electrochemical properties of lithium manganite cathode for rechargeable batteries. Surf. Coatings Technol. 2004, 177, 60-64. [CrossRef]

84. Kim, B.-H.; Choi, Y.-K.; Choa, Y.-H. Synthesis of $\mathrm{LiFe}_{\mathrm{x}} \mathrm{Mn}_{2}{ }_{\mathrm{x}} \mathrm{O}_{4}$ cathode materials by emulsion method and their electrochemical properties. Solid State Ionics 2003, 158, 281-285. [CrossRef]

85. Hashem, A.; Abdel-Ghany, A.; Abuzeid, H.; El-Tawil, R.; Indris, S.; Ehrenberg, H.; Mauger, A.; Julien, C. EDTA as chelating agent for sol-gel synthesis of spinel $\mathrm{LiMn}_{2} \mathrm{O}_{4}$ cathode material for lithium batteries. $J$. Alloys Compd. 2018, 737, 758-766. [CrossRef]

86. Xia, Y.; Takeshige, H.; Noguchi, H.; Yoshio, M. Studies on an Li Mn O spinel system (obtained by melt-impregnation) as a cathode for $4 \mathrm{~V}$ lithium batteries part 1 . Synthesis and electrochemical behaviour of $\mathrm{LixMn}_{2} \mathrm{O}_{4}$. J. Power Sources 1995, 56, 61-67. [CrossRef]

87. Ohzuku, T.; Kitagawa, M.; Hirai, T. Electrochemistry of manganese dioxide in lithium nonaqueous cell. III. X-ray diffractional study on the reduction of spinel-related manganese dioxide. J. Electrochem. Soc. 1990, 137, 769-775. [CrossRef]

88. Kanamura, K.; Naito, H.; Yao, T.; Takehara, Z.-I. Structural change of the $\mathrm{LiMn}_{2} \mathrm{O}_{4}$ spinel structure induced by extraction of lithium. J. Mater. Chem. 1996, 6, 33-36. [CrossRef]

89. Liu, W.; Kowal, K.; Farrington, G.C. Mechanism of the electrochemical insertion of lithium into $\mathrm{LiMn}_{2} \mathrm{O}_{4}$ spinels. J. Electrochem. Soc. 1998, 145, 459-465. [CrossRef]

90. Ebin, B.; Battaglia, V.; Gürmen, S. Comparison of $4 \mathrm{~V}$ and $3 \mathrm{~V}$ electrochemical properties of nanocrystalline $\mathrm{LiMn}_{2} \mathrm{O}_{4}$ cathode particles in lithium ion batteries prepared by ultrasonic spray pyrolysis. Ceram. Int. 2014, 40, 7029-7035. [CrossRef]

91. Zheng, Z.; Tang, Z.; Zhang, Z.; Shen, W.; Lin, Y. Surface modification of $\mathrm{Li}_{1.03} \mathrm{Mn}_{1.97} \mathrm{O}_{4}$ spinels for improved capacity retention. Solid State Ionics 2002, 148, 317-321. [CrossRef]

92. Zhang, X.; Jiang, W.J.; Mauger, A.; Gendron, F.; Julien, C.M.; Qilu, R. Minimization of the cation mixing in $\mathrm{Li}_{1+\mathrm{x}}(\mathrm{NMC})_{1-\mathrm{x}} \mathrm{O}_{2}$ as cathode material. J. Power Sources 2010, 195, 1292-1301. [CrossRef]

93. Hashem, A.M.; Abdel-Ghany, A.E.; Scheuermann, M.; Indris, S.; Ehrenberg, H.; Mauger, A.; Julien, C.M. Doped nanoscale NMC333 as cathode materials for Li-ion batteries. Materials 2019, 12, 2899. [CrossRef]

94. Huang, S.; Wen, Z.; Zhu, X.; Gu, Z. Preparation and electrochemical performance of Ag doped $\mathrm{Li}_{4} \mathrm{Ti}_{5} \mathrm{O}_{12}$. Electrochem. Commun. 2004, 6, 1093-1097. [CrossRef]

95. Ho, C.; Raistrick, I.D.; Huggins, R.A. Application of a-c techniques to the study of lithium diffusion in tungsten trioxide thin films. J. Electrochem. Soc. 1980, 127, 343-350. [CrossRef]

96. Bard, A.J.; Faulkner, L.R. Electrochemical Methods: Fundamentals and Applications; Wiley \& Sons, Inc.: New York, NY, USA, 2001; pp. 226-260.

97. Sun, Y.-K.; Myung, S.-T.; Park, B.-C.; Yashiro, H. Improvement of the electrochemical properties of $\mathrm{Li}\left[\mathrm{Ni}_{0.5} \mathrm{Mn}_{0.5}\right] \mathrm{O}_{2}$ by $\mathrm{AlF}_{3}$ coating. J. Electrochem. Soc. 2008, 155, A705-A710. [CrossRef]

98. Amine, K.; Liu, J.; Kang, S.; Belharouak, I.; Hyung, Y.; Vissers, D.; Henriksen, G. Improved lithium manganese oxide spinel/graphite Li-ion cells for high-power applications. J. Power Sources 2004, 129, 14-19. [CrossRef]

99. Mauger, A.; Julien, C.M. Surface modifications of electrode materials for lithium-ion batteries: Status and trends. Ionics 2014, 20, 751-787. [CrossRef]

100. Julien, C.M.; Mauger, A. Functional behavior of $\mathrm{AlF}_{3}$ coatings for high-performance cathode materials for lithium-ion batteries. AIMS Mater. Sci. 2019, 6, 406-440. [CrossRef]

101. Wang, G.; Zhang, Q.; Yu, Z.; Qu, M. The effect of different kinds of nano-carbon conductive additives in lithium ion batteries on the resistance and electrochemical behavior of the $\mathrm{LiCoO}_{2}$ composite cathodes. Solid State Ionics 2008, 179, 263-268.

102. Knon, N.H.; Mouck-Makanda, D.; Fromm, K.M. A review: Carbon additives in $\mathrm{LiMnPO}_{4}$ - and $\mathrm{LiCoO}_{2}$-based cathode composites for lithium ion batteries. Batteries (Basel) 2018, 4, 50.

103. Eftekhari, A. $\mathrm{LiMn}_{2} \mathrm{O}_{4}$ electrode prepared by gold-titanium codeposition with improved cyclability. J. Power Sources 2004, 130, 260-265. [CrossRef]

104. Lim, M.R.; Cho, W.I.; Kim, K.B. Preparation and characterization of gold-codeposited $\mathrm{LiMn}_{2} \mathrm{O}_{4}$ electrodes. J. Power Sources 2001, 92, 168-176. [CrossRef]

(C) 2020 by the authors. Licensee MDPI, Basel, Switzerland. This article is an open access article distributed under the terms and conditions of the Creative Commons Attribution (CC BY) license (http://creativecommons.org/licenses/by/4.0/). 